\title{
Faktor yang Memengaruhi Minat Muzaki dalam Membayar Zakat Melalui Kitabisa.com: Pendekatan Technology Acceptance Model dan Theory of Planned Behavior
}

\section{Factors Affecting Muzaki's Interest in Paying Zakat through Kitabisa.com: Technology Acceptance Model Approach and Theory of Planned Behavior}

\author{
Windi Astuti ${ }^{1}$, Budi Prijanto ${ }^{2}$ \\ ${ }^{1}$ Fakultas Ekonomi, Universitas Gunadarma, Jalan Margonda Raya 100, Depok, Indonesia, \\ windiastuti64@gmail.com \\ ${ }^{2}$ Fakultas Ekonomi, Universitas Gunadarma, Jalan Margonda Raya 100, Depok, Indonesia, \\ budi_prijanto@yahoo.com
}

\begin{abstract}
This study aims to examine the factors that influence muzaki's interest in paying zakat through Kitabisa.com with the Technology Acceptance Model and Theory of Planned Behavior approaches. In addition, this study analyzes the relationship pattern of the perceived usefulness, ease of use, attitudes, subjective norms, and behavioral control towards muzaki's interest. The method used in this study is a quantitative method using Structural Equation Modeling (SEM). The analytical tool used is the SmartPLS version 3 software. The data collection technique was through distributing questionnaires with a total sample of 180 respondents. The results showed that muzaki's interest in paying zakat through Kitabisa.com was influenced by perceptions of ease of use, attitudes, subjective norms, and perceptions of behavior control. This study proves that perceived ease of use has a significant effect on perceived usefulness. Perceived usefulness and perceived ease of use have a significant effect on attitudes. Meanwhile, perceived usefulness has no significant effect on the interest in using Kitabisa.com digital zakat services. In addition, perceptions of ease of use, attitudes, subjective norms, and perceptions of behavioral control have a significant effect on the interest in using Kitabisa.com digital zakat services.
\end{abstract}

Keywords: Digitalization of zakat, Kitabisa.com, muzaki's interest, Structural Equation Modeling (SEM), zakat.

\begin{abstract}
Abstrak. Penelitian ini bertujuan untuk mengkaji faktor-faktor yang memengaruhi minat muzaki dalam membayar zakat melalui Kitabisa.com dengan pendekatan Technology Acceptance Model dan Theory of Planned Behavior. Selain itu, penelitian ini menganalisis pola hubungan perspektif kemudahan, kegunaan, sikap, norma subjektif, dan kontrol perilaku terhadap minat muzaki. Metode yang digunakan pada penelitian ini yaitu metode kuantitatif dengan menggunakan Structural Equation Modeling (SEM). Alat analisis yang digunakan yaitu software SmartPLS versi 3. Teknik pengumpulan data primer melalui penyebaran kuesioner dengan jumlah sampel sebesar 180 responden. Hasil penelitian menunjukkan bahwa minat muzaki dalam membayar zakat melalui Kitabisa.com dipengaruhi oleh persepsi kemudahan penggunaan, sikap, norma subjektif, persepsi kontrol perilaku. Penelitian ini membuktikan bahwa persepsi kemudahan penggunaan berpengaruh signifikan terhadap persepsi kegunaan. Kemudian, persepsi kegunaan dan persepsi kemudahan penggunaan berpengaruh signifikan terhadap sikap. Sedangkan persepsi kegunaan tidak berpengaruh signifikan terhadap minat menggunakan layanan zakat digital Kitabisa.com. Di samping itu, persepsi kemudahan penggunaan, sikap, norma subjektif, dan persepsi kontrol perilaku berpengaruh signifikan terhadap minat menggunakan layanan zakat digital Kitabisa.com.
\end{abstract}

Kata kunci: Digitalisasi zakat, Kitabisa.com, minat muzaki, Structural Equation Model (SEM), zakat.

\section{PENDAHULUAN}

Indonesia menjadi salah satu dari 10 top the biggest population Muslim in the world pada tahun 2010, yaitu menempati urutan pertama sebanyak 209.1 juta jiwa atau 13.2\% dari jumlah populasi Muslim dunia (Suhendra, 2017). Total populasi penduduk Indonesia sendiri berjumlah 258.7 juta orang (BPS, 2016). 
Fakta di atas menunjukkan bahwa penduduk Indonesia mayoritas beragama Islam, sehingga tidak dapat dipungkiri bahwa Indonesia memiliki potensi zakat yang besar. Menurut BAZNAS, pada tahun 2019 Indonesia memiliki potensi zakat sebesar Rp 233.8 T dan terealisasi sebesar Rp 10.2 T. Adapun di bawah ini merupakan data potensi dan realisasi zakat di Indonesia selama beberapa tahun terakhir:

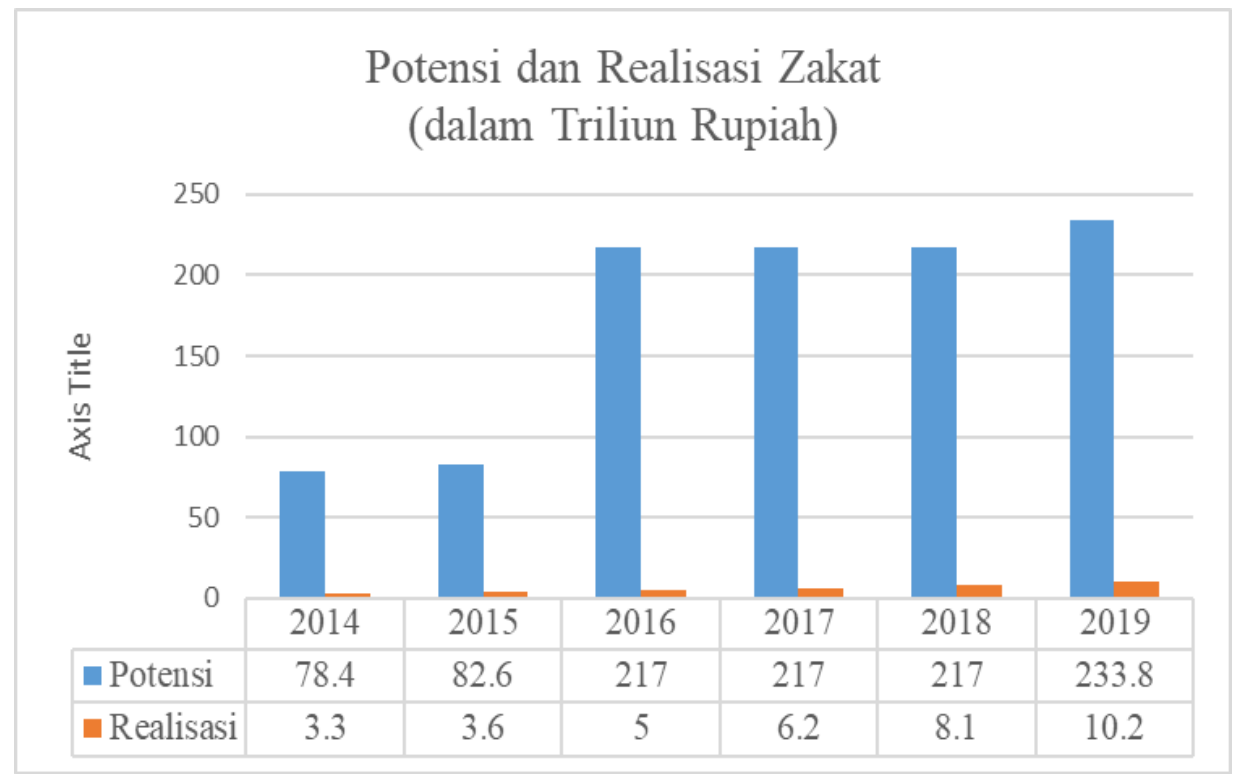

Sumber: BAZNAS, 2020 (diolah)

Gambar 1 Potensi dan realisasi zakat di Indonesia

Gambar 1 menunjukkan bahwa penghimpunan dana zakat yang terealisasi tiap tahunnya selama 5 tahun terakhir belum secara optimal mencapai besaran potensi yang dimiliki. Firmansyah (2013) menegaskan bahwa ada kesenjangan yang signifikan antara potensi dan realisasi zakat di Indonesia. Hal tersebut membuktikan terdapat gap yang besar antara potensi dengan dana zakat yang sudah terealisasi penghimpunannya. Di samping itu, tidak dapat dipungkiri bahwa setiap tahunnya penghimpunan dana zakat mengalami peningkatan. Hal tersebut merupakan respons yang bagus untuk memberikan stimulus dalam penghimpunan zakat.

Menurut Karim dan Syarief dalam Soekapdjo et al. (2019), Organisasi Pengelolaan Zakat (OPZ) mengalami pertumbuhan yang pesat karena faktor penarik dan pendorong. Faktor penariknya yaitu spirit of consciousness, spirit of innovation dan spirit of empowering. Sedangkan faktor pendorongnya adalah huge market potential, friendly regulation, IT Infrastructure, dan awareness increasing. Dengan demikian, huge market potential dan IT Infrastucture menjadi salah satu faktor pendorong pertumbuhan OPZ sehingga strategi digitalisasi zakat merupakan langkah yang cermat.

Pada era digital saat ini, kebijakan atas inovasi penghimpunan dana zakat berkaitan erat dengan pemanfaatan sistem teknologi informasi. Salah satu upaya masif yang sedang dikelola OPZ yaitu digitalisasi zakat, di mana pembayaran zakat dapat dilakukan secara online. Inovasi tersebut sebagai bentuk upaya optimalisasi penghimpunan dana zakat. Sebagai langkah melebarkan sayap untuk menarik lebih banyak umat Islam dalam membayar zakat, tak jarang OPZ membuat platform digital sendiri atau bahkan bekerjasama dengan perusahaan fintech. Hal ini dibuktikan oleh Hudaefi et al. (2020) yang dalam hasil studinya menemukan bahwa BAZNAS sebagai lembaga zakat di Indonesia telah mengembangkan platform online beserta aplikasi berbasis seluler. Selain itu, BAZNAS telah bekerjasama dengan perusahaan fintech dengan mengadakan layanan pembayaran zakat baik secara online maupun berupa scan kode QR. Upaya tersebut bertujuan untuk menghimpun dana zakat.

Pada dasarnya, keberadaan fintech memberikan kemudahan pelayanan di bidang keuangan seperti proses yang lebih cepat dan bersifat fleksibel. Atas dasar itu, OPZ mengambil langkah untuk bekerjasama dengan fintech, salah satunya yaitu layanan keuangan berjenis crowdfunding. Awal mula 22 
adanya crowdfunding di Indonesia ditandai dengan munculnya salah satu pionir yaitu Kitabisa.com pada tahun 2013. Kitabisa.com dikenal dengan gerakannya untuk bergotong-royong membantu kebaikan terhadap sesama.

Perkembangan Kitabisa.com dibuktikan dengan 531,353 orang tergabung sebagai pengguna, 11,650 penggalangan terdanai (Kitabisa.com, 2018). Sebagai start up crowdfunding yang mengawali kegiatan sosial berbentuk bantuan materiel dengan membuat sistem platform secara online dan perkembangannya yang sangat pesat, Kitabisa.com dipercaya oleh OPZ untuk membantu dalam mengupayakan penghimpunan dana zakat. Bentuk kerjasama ini diharapkan dapat meningkatkan realisasi dana zakat yang terkumpul.

Badan Amil Zakat Nasional (BAZNAS), Dompet Dhuafa dan Rumah Zakat menjadi OPZ yang bekerjasama dengan Kitabisa.com sebagai salah satu crowdfunding yang memiliki layanan zakat digital atau online sejak Juni 2016. Total donasi dan zakat yang berhasil Kitabisa.com kumpulkan pertahun 2016 pada tahun awal kerjasama sebesar Rp 61 M. Oleh karenanya, kerjasama ini diharapkan dapat meningkatkan penghimpunan dana zakat, melihat banyaknya dana donasi dan zakat yang berhasil terkumpul melalui Kitabisa.com pada tahun pertama kerjasama (Kitabisa.com, 2016).

Berdasarkan pemaparan di atas, kegiatan penghimpunan dana zakat pada Kitabisa.com berkaitan erat dengan IT Infrastructure. Kitabisa.com lebih dikenal dengan layanan crowdfunding yang mengumpulkan dana sosial terkhususnya kegiatan amal atau donasi dibandingkan dengan layanan zakatnya. Maka, hal ini harus diperhatikan apakah sistem teknologi informasi dan bentuk upaya digitalisasi zakat tersebut dapat meningkatkan minat dalam berzakat secara online. Dengan mengetahui hal tersebut, diharapkan dapat meningkatkan minat sehingga semakin banyak jumlah muzaki yang membayar zakat melalui Kitabisa.com. Upaya kerjasama tersebut dalam optimalisasi penghimpunan dana zakat, akan menjadi kurang berarti jika muzaki enggan menggunakan platform Kitabisa.com.

Sehubungan dengan hal di atas, dibutuhkan penilaian minat muzaki dalam penerimaan sebuah sistem teknologi informasi terkait penelitian ini yaitu fitur zakat di Kitabisa.com. Menurut Nasri dan Charfeddine dalam Indrayana et al. (2016), model yang dapat menjelaskan faktor apa saja yang memengaruhi penerimaan individu terhadap sistem teknologi informasi yaitu Technology of Acceptance Model (TAM). Faktor lain yang perlu diketahui selain penerimaan sistem teknologi informasi untuk mengukur minat pengguna yaitu perilaku. Menurut Peterson dalam Indrayana et al. (2016), minat pengguna merupakan prediktor penting dari perilaku orang tersebut.

Studi Khalil, et al. (2020) menggunakan model TPB sebagai model dasar dalam menjelaskan niat berperilaku untuk mematuhi pembayaran zakat. Model TPB yang dibentuk oleh studi tersebut untuk menentukan intensi perilaku atau niat membayar zakat gaji melalui sikap, norma subjektif, kontrol perilaku, dan takwa. Atas hal tersebut, pada penelitian ini minat ditentukan oleh sikap, norma-norma subjektif (subjective norms) dan persepsi kontrol perilaku terhadap perilaku yang akan dilakukan. Faktor-faktor tersebut merupakan bagian dari sebuah model yaitu Theory of Planned Behavior (TPB).

Adapun kedua model tersebut yaitu Technology of Acceptance Model (TAM) dan Theory of Planned Behavior (TPB), memiliki kesamaan ialah perilaku seseorang dibentuk oleh minat dan sikap dalam bertindak. Kedua model ini tak jarang digunakan untuk menilai tingkat penerimaan pengguna terhadap suatu layanan berbasis teknologi informasi atau mengetahui perilaku penggunanya. Berdasarkan hal tersebut, penulis tertarik untuk meneliti terkait "Faktor yang Memengaruhi Minat Muzaki dalam Membayar Zakat melalui Kitabisa.com: Pendekatan Technology Acceptance Model dan Theory of Planned Behavior". 


\section{TINJAUAN PUSTAKA}

\section{Digitalisasi Zakat}

Zakat merupakan ibadah maliyah ijtima'iyah atau sosial kebendaan dan salah satu rukun Islam yang wajib dilakukan oleh umat Islam (Adhiatma dan Fachrunnisa, 2021). Menurut Sarwat (2019), makna lain zakat diartikan dalam Al-Qur'an yaitu suci (menyucikan diri). Zakat berarti subur atau tumbuh, dengan kata lain Al-Qardhawi mengartikan pembayaran zakat dirancang untuk memungkinkan para mustahik tumbuh dalam kekayaan dan jiwa (Sulaeman dan Ninglasari, 2020). Maka, jika dirumuskan secara rinci zakat dapat diartikan bagian dari harta yang wajib dikeluarkan oleh setiap Muslim yang telah memenuhi syarat tertentu kepada orang yang berhak menerimanya.

Inovasi sistem penghimpunan dan penyaluran sesuai dengan perkembangan zaman agar masyarakat yang ingin berzakat semakin mudah sehingga diharapkan meningkatnya penghimpunan dana zakat. Pada era digital saat ini, kebijakan atas inovasi penghimpunan dana zakat berkaitan erat dengan pemanfaatan sistem teknologi informasi. Salah satu upaya masif yang sedang dikelola OPZ yaitu digitalisasi zakat, di mana pembayaran zakat dapat dilakukan secara online.

Menurut Dian F dalam Irhamsyah (2019) menjelaskan bahwa dengan menggunakan fintceh untuk menghimpun dana zakat dapat mengakses layanan zakat menjadi lebih mudah dan cepat, menjangkau masyarakat perkotaan dan pedesaan, biaya transaksi lebih murah dan efisien, sistem manajemen secara real time, dan jumlah transaksi yang besar. Fenomena digitalisasi zakat juga terjadi secara global, bukan hanya di Indonesia. Di Malaysia, sebagian besar lembaga zakat sudah mulai memanfaatkan sistem teknologi terutama terkait pembayaran zakat. Pemanfaatan teknologi meningkatkan efisiensi dan efektivitas operasional lembaga zakat (Salleh dan Chowdhury, 2020). Di India, inovasi digitalisasi zakat seperti ATM beras, aplikasi berbasis ponsel seluler, aplikasi yang dibuat dengan teknologi blockchain dan kecerdasan buatan berperan penting dalam pengelolaan zakat yang efektif (Muneeza dan Nadwi, 2019). Selain itu, BAZNAS sebagai lembaga zakat di Indonesia menyambut dengan hangat pengembangan zakat berbasis teknologi (Hudaefi et al., 2020).

Dengan demikian, untuk memperluas jejaring pembayaran zakat, OPZ bekerjasama dengan crowdfunding. Fintech berjenis crowdfunding merupakan bentuk penggalangan atau penghimpunan dana yang bersumber dari masyarakat luas untuk disalurkan baik untuk sebuah proyek, produk, maupun kegiatan sosial yang dipelopori oleh orang maupun kelompok (Wildan, 2019). Sehingga bukan hanya dapat melakukan pembayaran zakat melalui sistem informasi OPZ terkait, namun juga bisa melalui crowdfunding yang telah bekerjasama (Hudaefi et al., 2020). Penghimpunan melalui sistem teknologi informasi berguna untuk meyakinkan masyarakat bahwa penghimpunan dan penyaluran dana secara real time diketahui berapa banyak yang telah terkumpul dan disalurkan dana zakatnya. Tidak hanya itu, perusahaan fintech telah mempromosikan gagasan keuangan inklusi yaitu melakukan pembiayaan bagi UMKM, mengumpulkan dan mendistribusikan dana finlantropi Islam dan memprakarsai program amal untuk masyarakat kurang mampu (Hudaefi, 2020).

Digitalisasi zakat pada crowdfunding masuk ke dalam jenis donation-based crowdfunding. Hal ini dikarenakan pembayaran zakat tanpa berharap imbal balik atau imbalan dari pembayaran tersebut. Pembayaran zakat didasarkan keridaan untuk mensucikan hartanya beserta dirinya. Awal mula adanya donation-based crowdfunding di Indonesia ditandai dengan munculnya salah satu pionir yaitu Kitabisa.com pada tahun 2013. Kitabisa.com dikenal dengan gerakannya yaitu bergotong-royong membantu kebaikan terhadap sesama. Sehubungan dengan itu, beberapa OPZ bekerjasama dengan Kitabisa.com yaitu BAZNAS, NUCare-Lazis, LazisMu, Rumah Zakat, dan Dompet Dhuafa. Pada dasarnya, crowdfunding yang telah dipercayai untuk melakukan kerjasama penghimpunan zakat harus melakukan tanggung jawab sebagaimana mestinya. Adapun dasar hukum syariah yang mengatur hal tersebut (Wildan, 2019): 


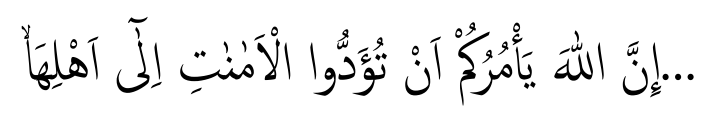

"Sesungguhnya Allah menyuruh kamu menyampaikan amanat kepada yang berhak merimanya...." (QS. An-Nisa, 4:58)

Berdasarkan Surat An-Nisa ayat 58, dapat diambil hikmah yaitu penghimpunan zakat secara digital bahwa sebenarnya crowdfunding menjaga amanat muzaki dan OPZ serta menyampaikannya kepada mustahik. Tujuannya yaitu agar kepercayaan publik tumbuh baik kepada OPZ untuk disalurkan ke platform yang bekerjasama.

"Tunaikanlah amanah (titipan) kepada yang berhak menerimanya dan janganlah membalas khianat orang yang menghianatimu” (HR. Abu Daud dan Tirmidzi dari Abu Hurairah)

Hadis di atas mengajari bahwa menjaga dan menyampaikan amanah adalah suatu yang penting dalam hal ini yaitu kerjasama antarpihak baik OPZ, crowdfunding, muzaki, mustahik, dan pihak yang terlibat lainnya. Hal ini agar terciptanya kepercayaan antarpihak dan tidak ada pihak yang merasa dirugikan.

Adapun tinjauan dari fikih zakat mengenai pembayaran zakat secara online apakah sah atau tidak telah dibahas sebelumnya. Dengan catatan terpenuhinya unsur penting dalam zakat yaitu pemberi zakat (muzaki), penerima zakat (mustahik), harta zakat, dan niat (pernyataan zakat dan doa penerima zakat). Selain itu, syarat atas harta yang wajib dizakati sudah terpenuhi yaitu harta dikuasi secara penuh, harta memiliki potensi untuk berkembang, mencapai nisab, dan haul (Hafidhuddin dalam Kholid, 2018).

Berdasarkan inovasi penghimpunan zakat tersebut diperlukan kajian minat muzaki dalam penerimaan sebuah sistem teknologi informasi. Hal ini karena kegiatan penghimpunan dana zakat pada Kitabisa.com berkaitan erat dengan IT Infrastructure. Kitabisa.com lebih dikenal dengan layanan crowdfunding yang mengumpulkan dana sosial terkhususnya kegiatan amal atau donasi dibandingkan dengan layanan zakatnya. Maka, hal ini harus diperhatikan apakah sistem teknologi informasi dan bentuk upaya digitalisasi zakat tersebut dapat meningkatkan minat dalam berzakat secara online.

Model yang dapat menjelaskan faktor apa saja yang memengaruhi penerimaan individu terhadap sistem teknologi informasi yaitu Technology of Acceptance Model (TAM) dan Theory of Planned Behaviour (TPB). Awal mula terbentuknya model tersebut, didasari oleh Theory Reasoned Action (TRA) ditemukan oleh Fishbein dan Ajzen pada tahun 1975. Teori ini dibuat atas asumsi dasar yaitu manusia merupakan makhluk hidup dengan daya nalar menggunakan akal untuk memutuskan perilaku yang akan dilakukan secara sadar dengan mempertimbangkan informasi yang dimiliki. Pada teori ini, minat individu dalam berperilaku dipengaruhi oleh dua faktor penentu dasar yaitu sikap terhadap perilaku (attitude toward behavior) dan norma subyektif (subjective norm) (Jogiyanto, 2007).

\section{Pengembangan Hipotesis}

Theory Reasoned Action (TRA) atau teori tindakan beralasan memaparkan bahwa terdapat tahapantahapan manusia memutuskan untuk melakukan suatu perilaku. Menurut Amalia (2018), tahapannya yaitu pertama, perilaku (behavior) ditentukan oleh niat (intention). Kedua, niat (intention) dijelaskan dalam bentuk sikap terhadap perilaku (attitude toward behavior) dan norma subyektif (subjective norm). Ketiga, sikap (attitude) dan norma subyektif (subjective norm) dijelaskan dalam bentuk kepercayaan atas konsekuensi dari melakukan suatu perilaku dan kepercayaan normatif yang direferensikan. 


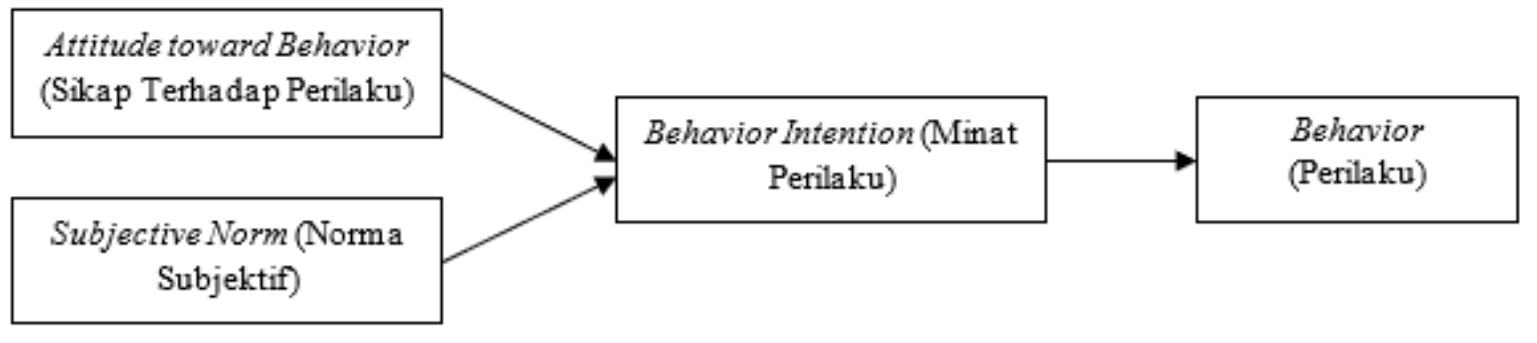

Sumber: Jogiyanto, 2007

Gambar 2 Model Theory Reasond Action (TRA)

Amalia (2018) menjelaskan bahwa niat (intention) dapat disebut keinginan yang memengaruhi dalam melakukan suatu perilaku. Perilaku (behavior) merupakan kegiatan secara nyata dilakukan. Sikap terhadap perilaku (attitude toward behavior) yaitu evaluasi baik positif atau negatif manusia untuk melakukan perilaku tersebut. Norma subjektif (subjective norm) merupakan persepsi orang lain atas sebuah tindakan yang akan memengaruhi keyakinan individu untuk melakukan atau tidak suatu perilaku. Dapat disimpulkan, norma subjektif menunjukkan bahwa adanya pengaruh sosial atas perilaku individu atau perilaku tersebut dipengaruhi oleh pendapat seseorang (Jogiyanto, 2007).

Pada minat penggunaan suatu layanan berbasis teknologi informasi, maka tidak hanya ditentukan oleh sikap pribadi, namun juga mempertimbangkan pendapat terkait perilaku orang lain dalam memakai teknologi tersebut. Hal ini dikarenakan jika diasumsikan mereka memercayai satu atau lebih referensi atas perilaku tersebut, maka akan memberikan efek termotivasi untuk mengikuti minat dari referensi tersebut. Sehingga, dapat disimpulkan bahwa sikap terhadap perilaku (attitude toward behavior) dan norma subjektif (subjective norm) akan menentukan minat untuk melakukan suatu perilaku atau dalam hal ini yaitu penggunaan layanan berbasis teknologi informasi.

Technology Acceptance Model (TAM) diperkenalkan pertama kali oleh Davis et al. pada 1989, merupakan adaptasi dari Theory Reasond Action (TRA) atau teori tindakan beralasan yaitu untuk mengidentifikasi perilaku penerimaan sistem dan teknologi informasi. Menurut Fishbein dan Ajzen pencetus TRA bahwa perilaku didasari oleh niat individu untuk melakukan suatu kegiatan tertentu. Pada TRA, niat ditentukan oleh dua faktor yaitu sikap terhadap perilaku (attitude toward behavior) dan norma subjektif (subjective norm). Oleh karena itu, diasumsikan individu berperilaku bukan hanya berdasarkan persepsinya namun juga mengenai pendapat orang lain terhadap apa yang ia harus lakukan.

Pengembangan teori yang dilakukan oleh Davis et al. (1989) yaitu terletak pada pemahaman perilaku pemakai sistem teknologi informasi dalam menerima dan menggunakan sistem tersebut. Pengembangan teori TRA ini guna menciptakan TAM untuk memberikan informasi mengenai faktorfaktor pendorong dan memprediksi sikap serta penerimaan seseorang terhadap sistem teknologi informasi.

TAM memiliki 2 variabel yang menentukan minat untuk menerima sistem dan teknologi informasi yaitu persepsi kegunaan (perceived usefulness) dan persepsi kemudahan penggunaan (perceived ease of use). Persepsi kegunaan (perceived usefulness) merupakan tingkat kepercayaan pengguna yang dapat menunjukkan bahwa pengguna sistem teknologi informasi akan berminat menggunakan sistem tersebut jika berguna untuk meningkatkan kinerjanya. Persepsi kemudahan penggunaan (perceived ease of use) merupakan tingkat kepercayaan atau keyakinan pengguna yang dapat menunjukkan bahwa pengguna sistem teknologi informasi akan berminat jika mudah digunakan (Mahendra, 2014).

Menurut Widyaharsana dalam Amalia (2018), model ini menggambarkan bagaimana respons pengguna ketika dihadapkan untuk menggunakan teknologi baru dan dipengaruhi oleh beberapa faktor dalam keputusannya untuk menggunakan teknologi tersebut. Adanya pengaruh dari beberapa faktor karena Davis et al. (1989) menambahkan dua konstruk ke dalam model TRA sebagai 
pengembangan dan adopsinya yaitu persepsi kegunaan (perceived usefulness) dan persepsi kemudahan penggunaan (perceived ease of use). Maka, penambahan dua konstruk atau variabel tersebut menjadi kesatuan dengan model TRA disebut dengan TAM. Berikut ini model Technology Acceptance Model (TAM):

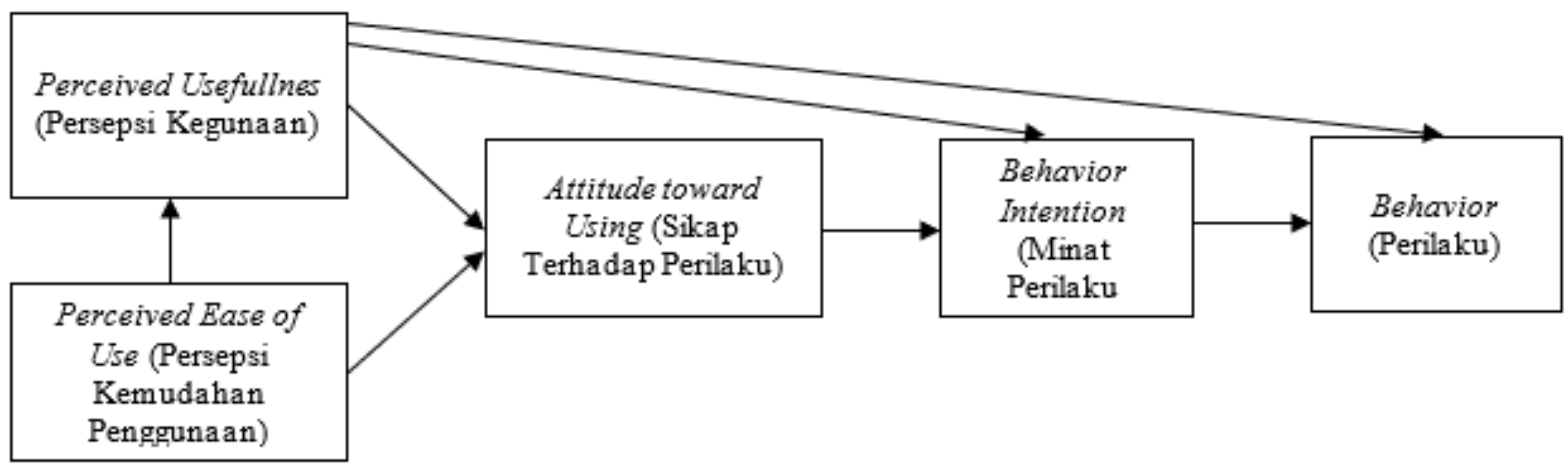

Sumber: Jogiyanto, 2007

\section{Gambar 3 Model Technology Acceptance Model (TAM)}

Menurut Iqbal dalam Amalia (2018), TAM dapat menjelaskan hubungan dari sebab akibat antara keyakinan dengan perilaku, tujuan atau keperluan, dan penggunaan aktual dari pengguna sistem teknologi informasi tersebut. Faktor kepercayaan atau keyakinan dari perilaku dengan menempatkan dua variabel yaitu persepsi kegunaan (perceived usefulness) dan persepsi kemudahan penggunaan (perceived ease of use). Menurut Davis et al. (1989), manfaat yang dirasakan akan dilihat dari tingkat penggunaan produk atau layanan guna meningkatkan kemampuan pengguna untuk mencapai tujuan yang diinginkan. Sedangkan kemudahan penggunaan dilihat dari sejauh mana layanan berbasis teknologi bebas dari upaya.

Oleh karena itu, penulis mengambangkan hipotesis penelitian berdasarkan teori TAM dimana $\mathrm{H}_{1}$ yaitu persepsi kemudahan penggunaan berpengaruh signifikan terhadap sikap. Selain itu, terdapat $\mathrm{H}_{2}$ yang didasari oleh teori ini yaitu persepsi kegunaan berpengaruh terhadap sikap. Adapun $\mathrm{H}_{3}$ yang didasari oleh teori tersebut yaitu persepsi kemudahan penggunaan berpengaruh signifikan terhadap persepsi kegunaan. Dari teori original TAM tersebut dapat membentuk $\mathrm{H}_{4}$ yaitu persepsi kegunaan berpengaruh signifikan terhadap minat. Sedangkan, $\mathrm{H}_{5}$ dibentuk berdasarkan teori parsimonious TAM yaitu persepsi kemudahan penggunaan berpengaruh signifikan terhadap minat.

Dengan demikian, definisi penerimaan pengguna terhadap sistem teknologi informasi yaitu niat atau minat yang nampak pada pengguna untuk menggunakan sistem teknologi informasi ke dalam suatu aktivitasnya. Diharapkan perkembangan teknologi saat ini digunakan sebaik mungkin sehingga menghasilkan kemudahan dan kebermanfaatan yang diterima oleh pengguna tersebut. Sehingga pada akhirnya akan memberikan manfaat pula bagi perusahaan pengembang sistem teknologi informasi tersebut.

Theory of Planned Behavior (TPB) merupakan model dari pengembangan Theory Reasond Action (TRA) dengan menambahkan variabel persepsi kontrol perilaku (perceived behavioural control) sebagai penyempunaan dari TRA. Menurut Winarko dan Mahadwai dalam Amalia (2018), penambahan variabel tersebut untuk mengetahui persepsi seseorang terhadap tingkat kemudahan maupun kesulitan dalam melakukan perilaku. Oleh karena itu, pada TPB terdapat variabel penting dalam menentukan minat yaitu sikap (attitude), norma subjektif (subjective norm), dan persepsi kontrol perilaku (perceived behavioral control).

Amalia (2018) mengasumsikan bahwa pada persepsi kontrol perilaku terdapat implikasi motivasional terhadap niat. Bagi orang-orang yang percaya bahwa ketidakpunyaan mereka terhadap sumber daya atau tidak punya kesempatan untuk melakukan perilaku tertentu memungkinkan tidak akan 
membentuk minat perilaku yang kuat walaupun memungkinkan melakukan perilaku tersebut. Maka hal ini menunjukkan bahwa perilaku tidak tergantung hanya pada motivasi tetapi juga kontrol pada perilaku yang dilakukan. Persepsi kontrol perilaku (perceived behavioral control) secara tidak langsung dapat memengaruhi perilaku melalui niat dan dapat memprediksi perilaku secara langsung. Dengan demikian, model dari Theory of Planned Behavior (TPB) sebagai berikut:

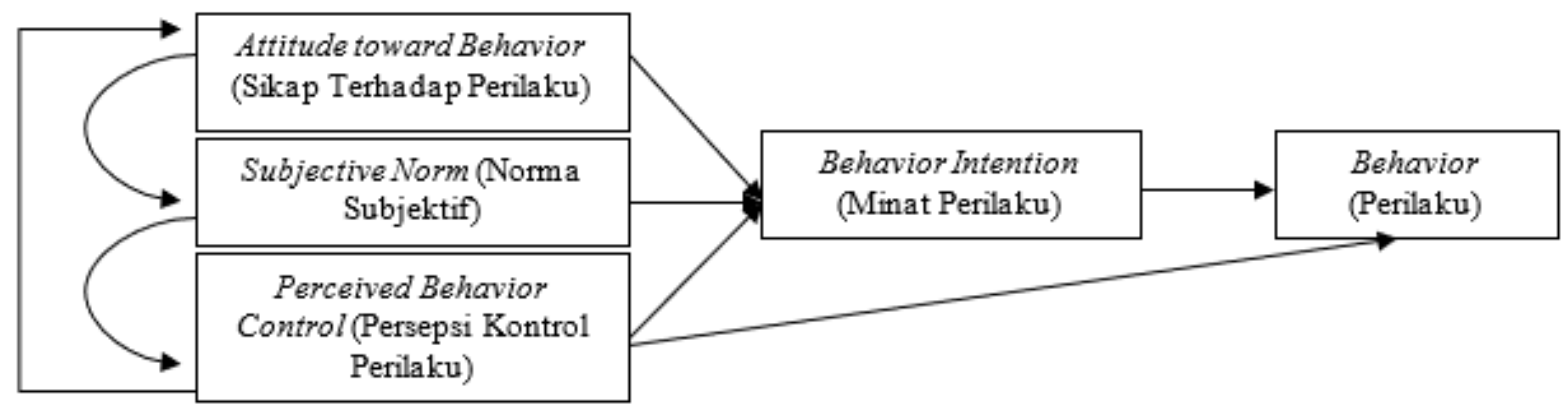

Sumber: Jogiyanto, 2007

Gambar 4 Model Theory of Planned Behavior (TPB)

Pada Theory of Planned Behavior (TPB), niat (intention) merupakan faktor penting dalam melakukan tindakan atau perilaku. Niat (intention) dianggap mampu untuk menarik faktor-faktor motivasional yang dapat memengaruhi perilaku. Adanya faktor motivasional dapat menunjukkan seberapa kuat niat (intention) untuk berusaha dan seberapa besar usaha untuk melakukannya. Faktor-faktor motivasional tersebut pada keinginan perilaku (behavioral intention) terdiri dari sikap (attitude), norma subjektif (subjective norm), dan persepsi kontrol perilaku (perceived behavioral control) (Jogiyanto, 2007).

Menurut Fishbein dan Ajzen, sikap merupakan perasaan yang dirasakan oleh seseorang untuk menerima atau menolak suatu objek atau perilaku dengan menempatkan individual pada pengukuran evaluasi dua sisi yaitu baik atau buruk, menerima atau menolak dan lain sebagainya (Amalia, 2018). Maka dalam hal ini, sikap yang diperlihatkan pengguna sistem teknologi informasi menunjukkan seberapa besar pengguna tersebut merasakan baik atau buruk sistem tersebut. Adapun norma subjektif ialah faktor sosial yang didasari dari kepercayaan orang lain yang dapat memengaruhi minat sehingga akan menjadi bahan pertimbangan dalam melakukan atau tidaknya perilaku tersebut. Sedangkan persepsi kontrol perilaku merupakan persepsi seseorang terkait kemudahan atau kesulitan dalam melaksanakan suatu tindakan.

Oleh karena itu, penulis juga membentuk hipotesis penelitian ini berdasarkan teori TPB dimana $\mathrm{H}_{6}$ yaitu norma subjektif berpengaruh signifikan terhadap minat. Adapun $\mathrm{H}_{7}$ yaitu persepsi kontrol perilaku berpengaruh signifikan terhadap minat. Berdasarkan teori TPB kemudian dapat dibentuk $\mathrm{H}_{8}$ yaitu sikap berpengaruh signifikan terhadap minat.

Thaker et al. (2018) dalam penelitiannya membuktikan bahwa perceived usefulness (PU) dan perceived ease of use (PEOU) berpengaruh positif signifikan terhadap niat menggunakan crowdfunding waqf model. Selain itu, perceived ease of use (PEOU) berpengaruh positif terhadap perceived usefulness (PU).

Amalia (2018) dalam penelitiannya mengemukakan bahwa minat dalam menggunakan aplikasi Paytren sebagai alat transaksi pembayaran dipengaruhi oleh persepsi manfaat (perceived usefulness) dan sikap (attitude). Persepsi kemudahan penggunaan (PEOU) berpengaruh positif dan signifikan terhadap variabel persepsi manfaat (PU) dengan besar kontribusi sebesar 64.4\%.

Mahendra (2014) melalui studi penelitiannya memaparkan bahwa minat penggunaan mobile banking dengan pendekatan TAM dan TPB menunjukkan bahwa persepsi kegunaan, sikap dan kontrol perilaku memengaruhi minat individu menggunakan mobile banking. Sebaliknya, persepsi kemudahan penggunaan dan norma subjektif tidak memengaruhi minat individu menggunakan mobile banking. 
Indrayana et al. (2016) dalam penelitiannya membuktikan bahwa norma subyektif berpengaruh signifikan terhadap minat menggunakan instagram untuk pembelian online. Faktor kontrol perilaku, kegunaan dan sikap berpengaruh namun tidak signifikan. Sikap merupakan faktor yang memiliki pengaruh yang paling besar.

\section{METODE}

Penelitian ini merupakan a single case study atau studi kasus dari Kitabisa.com. Pengumpulan data pada penelitian ini menggunakan kuesioner yang dibagikan kepada muzaki Kitabisa.com dengan mendistribusikannya melalui media sosial dalam rentang waktu Mei-Agustus 2020. Populasi dalam penelitian ini adalah pengguna Kitabisa.com, sedangkan kriteria sampel yang digunakan yaitu pengguna Kitabisa.com yang pernah melakukan pembayaran zakat di platform tersebut. Kriteria tersebut digunakan karena responden dianggap mengerti tujuan dari topik yang dibahas melalui itemitem pertanyaan (indikator) pada penelitian ini. Penentuan jumlah responden dihitung dengan menggunakan statistical power dan effect size oleh Cohen dalam Haryono (2017).

Pada penelitian ini jumlah anak panah terbesar dalam satu konstruk adalah 8 dengan $5 \%$ nilai signifikan dan $R$-square minimum sebesar 0.1 sehingga diperoleh jumlah minimal 174 sampel. Perolehan tersebut sebagai persyaratan jumlah minimal penggunaan sampel pada penelitian ini. Maka penelitian ini menggunakan 180 sampel.

Penelitian ini menggunakan metode SEM (Structural Equation Modelling) dengan alat analisis SmartPLS. Menurut Sholihin dalam Amalia (2018), metode SEM mampu menguji model penelitian secara komprehensif dan menganalisis variabel yang tidak dapat diukur langsung serta memperhitungkan kesalahannya. Oleh karena itu, SEM dianggap cocok bagi model penelitian yang kompleks. Model pengukuran dilakukan dengan uji validitas dan reabilitas, sedangkan model struktural dengan menggunakan uji signifikansi pada $f$ Square, $R$ Square dan bootstrapping.

Pada metode SEM terdapat dua variabel yaitu laten dan teramati. Variabel laten yang berasal dari Technology Acceptance Model (TAM) yaitu persepsi kegunaan, persepsi kemudahan penggunaan, sikap, dan minat. Sedangkan variabel laten yang berasal dari Theory of Planned Behavior (TPB) yaitu sikap, norma subjektif, persepsi kontrol perilaku, dan minat.

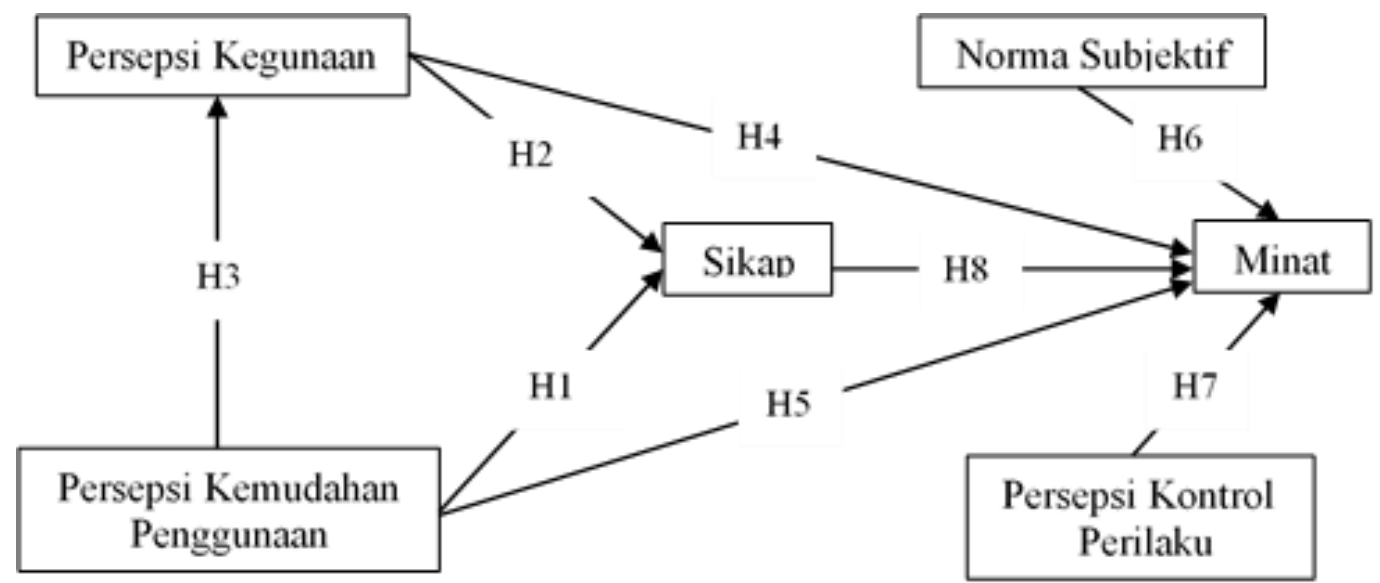

Sumber: Ilustrasi penulis, 2020

Gambar 5 Model penelitian pendekatan TAM dan TPB 
Berikut di bawah ini variabel laten dan teramati guna dijadikan model penelitian:

Tabel 1 Definisi operasional variabel

\begin{tabular}{|c|c|c|c|}
\hline $\begin{array}{l}\text { Variabel } \\
\text { Laten Eksogen }\end{array}$ & Indikator & Simbol & Sumber \\
\hline \multirow{4}{*}{$\begin{array}{l}\text { Persepsi } \\
\text { Kemudahan } \\
\text { Penggunaan } \\
\text { (Perceived } \\
\text { Ease of Use) } \\
\text { X1 }\end{array}$} & Kitabisa.com mudah digunakan & Kemudahan1 & \multirow{4}{*}{$\begin{array}{l}\text { (Amalia, } \\
\text { 2018); } \\
\text { (Indrayana et } \\
\text { al., 2016); } \\
\text { (Duy, 2012); } \\
\text { (Mahendra, } \\
\text { 2014) }\end{array}$} \\
\hline & $\begin{array}{l}\text { Instruksi tata cara pembayaran zakat jelas dan } \\
\text { mudah dimengerti }\end{array}$ & Kemudahan 2 & \\
\hline & $\begin{array}{l}\text { Kitabisa.com dapat digunakan di mana dan kapan } \\
\text { saja }\end{array}$ & Kemudahan 3 & \\
\hline & Kitabisa.com harus bersifat user-friendly & Kemudahan 4 & \\
\hline \multirow{3}{*}{$\begin{array}{l}\text { Norma } \\
\text { Subjektif } \\
\text { (Subjective } \\
\text { Norm) X2 }\end{array}$} & $\begin{array}{llll}\text { Lingkungan } & \text { sosial } & \text { menyarankan } & \text { penggunaan } \\
\text { Kitabisa.com } & & & \\
\end{array}$ & Norma1 & \multirow{3}{*}{$\begin{array}{l}\text { (Amalia, } \\
\text { 2018); } \\
\text { (Indrayana et } \\
\text { al., 2016); } \\
\text { (Duy, 2012); } \\
\text { (Mahendra, } \\
\text { 2014) }\end{array}$} \\
\hline & Lingkungan sosial menggunakan Kitabisa.com & Norma2 & \\
\hline & $\begin{array}{l}\text { Orang-orang di lingkungan sekitar saya berpikir } \\
\text { bahwa menggunakan Kitabisa.com adalah ide yang } \\
\text { baik }\end{array}$ & Norma 3 & \\
\hline \multirow{3}{*}{$\begin{array}{l}\text { Persepsi } \\
\text { Kontrol } \\
\text { Perilaku } \\
\text { (Perceived } \\
\text { Behavioral } \\
\text { Control) X3 }\end{array}$} & $\begin{array}{llll}\text { Mempunyai kemampuan untuk menggunakan } \\
\text { Kitabisa.com }\end{array}$ & Kontrol1 & \multirow{3}{*}{$\begin{array}{l}\text { (Amalia, } \\
\text { 2018); (Duy, } \\
\text { 2012); } \\
\text { (Mahendra, } \\
\text { 2014); } \\
\text { (Indrayana et } \\
\text { al., 2016) }\end{array}$} \\
\hline & $\begin{array}{l}\text { Memiliki pengetahuan untuk membayar zakat } \\
\text { melalui Kitabisa.com }\end{array}$ & Kontrol2 & \\
\hline & $\begin{array}{l}\text { Memiliki sumber daya untuk membayar zakat } \\
\text { melalui Kitabisa.com }\end{array}$ & Kontrol3 & \\
\hline $\begin{array}{l}\text { Variabel } \\
\text { Laten } \\
\text { Endogen }\end{array}$ & Indikator & Simbol & Sumber \\
\hline \multirow{4}{*}{$\begin{array}{l}\text { Persepsi } \\
\text { Kegunaan } \\
\text { (Perceived } \\
\text { Usefulness) Y1 }\end{array}$} & Meningkatkan fleksibilitas & Kegunaan1 & \multirow{4}{*}{$\begin{array}{l}\text { (Duy, 2012); } \\
\text { (Mahendra, } \\
\text { 2014); } \\
\text { (Amalia, } \\
\text { 2018); } \\
\text { (Indrayana et } \\
\text { al., 2016); } \\
\text { (Kholid, } \\
\text { 2018) }\end{array}$} \\
\hline & Mempercepat proses pembayaran & Kegunaan2 & \\
\hline & $\begin{array}{l}\text { Membantu pengguna untuk memilih disalurkan ke } \\
\text { program penyaluran dana zakat yang diinginkan }\end{array}$ & Kegunaan3 & \\
\hline & $\begin{array}{l}\text { Pembayaraan zakat melalui Kitabisa.com lebih } \\
\text { mudah dibandingkan secara konvensional }\end{array}$ & Kegunaan4 & \\
\hline \multirow[t]{4}{*}{$\begin{array}{l}\text { Sikap } \\
(\text { Attitude) Y2 }\end{array}$} & $\begin{array}{l}\text { Menggunakan Kitabisa.com untuk melakukan } \\
\text { pembayaran zakat merupakan ide yang baik }\end{array}$ & Sikap1 & \multirow{4}{*}{$\begin{array}{l}\text { (Amalia, } \\
\text { 2018); } \\
\text { (Indrayana et } \\
\text { al., 2016); } \\
\text { (Duy, 2012); } \\
\text { (Mahendra, } \\
\text { 2014); }\end{array}$} \\
\hline & $\begin{array}{l}\text { Zakat yang telah dibayarkan dapat disalurkan ke } \\
\text { program penyaluran dana zakat merupakan tindakan } \\
\text { yang bijak }\end{array}$ & Sikap2 & \\
\hline & Menyukai layanan zakat digital Kitabisa.com & Sikap3 & \\
\hline & $\begin{array}{l}\text { Dapat dipercaya sebagai crowdfunding yang telah } \\
\text { bekeriasama dengan lembaga zakat }\end{array}$ & Sikap4 & \\
\hline \multirow{4}{*}{$\begin{array}{l}\text { Minat untuk } \\
\text { Menggunakan } \\
\text { (Intention to } \\
\text { Use) Y3 }\end{array}$} & $\begin{array}{l}\text { Berencana menggunakan Kitabisa.com untuk } \\
\text { melakukan pembayaran zakat }\end{array}$ & Minat1 & \multirow{4}{*}{$\begin{array}{l}\text { (Duy, 2012); } \\
\text { (Mahendra, } \\
\text { 2014); } \\
\text { (Amalia, } \\
\text { 2018); } \\
\text { (Indrayana et } \\
\text { al., 2016) }\end{array}$} \\
\hline & Berniat menggunakan Kitabisa.com & Minat2 & \\
\hline & $\begin{array}{l}\text { Berkeinginan menggunakan Kitabisa.com untuk } \\
\text { mendukung program-program penyaluran dana } \\
\text { zakat }\end{array}$ & Minat3 & \\
\hline & $\begin{array}{l}\text { Berkeinginan menggunakan layanan pembayaran } \\
\text { zakat secara digital ke dalam jenis transaksi } \\
\text { pembayaran zakat favorit saya }\end{array}$ & Minat4 & \\
\hline
\end{tabular}




\section{HASIL DAN PEMBAHASAN}

\section{Karakteristik Responden}

Penelitian ini menggunakan 180 responden berdasarkan pertimbangan yang sudah dijelaskan pada bagian metode. Analisis data penelitian dimulai dari mengetahui deskriptif karakteristik responden dari segi usia, tingkat pendidikan, pekerjaan sampai dengan intensitas penggunaan Kitabisa.com. Hal ini guna mengetahui bagaimana perbedaan latar belakang dapat memengaruhi pandangan terhadap item-item pertanyaan (indikator) yang diajukan sebelumnya pada kuesioner.

Tabel 2 Karakteristik responden

\begin{tabular}{|c|c|c|c|}
\hline Karakteristik & Responden & Total & $\%$ \\
\hline \multirow[t]{7}{*}{ Usia } & $<21$ tahun & 21 & $12 \%$ \\
\hline & $21-25$ tahun & 91 & $51 \%$ \\
\hline & 26-30 tahun & 49 & $27 \%$ \\
\hline & $31-35$ tahun & 13 & $7 \%$ \\
\hline & $36-40$ tahun & 3 & $2 \%$ \\
\hline & $41-50$ tahun & 3 & $2 \%$ \\
\hline & $>50$ tahun & 0 & $0 \%$ \\
\hline \multirow[t]{6}{*}{ Tingkat Pendidikan } & SMA/SMK & 41 & $23 \%$ \\
\hline & D3 & 15 & $8 \%$ \\
\hline & S1 & 102 & $57 \%$ \\
\hline & S2 & 20 & $11 \%$ \\
\hline & S3 & 0 & $0 \%$ \\
\hline & Lain-lain & 2 & $1 \%$ \\
\hline \multirow[t]{6}{*}{ Pekerjaan } & Pengusaha & 18 & $10.0 \%$ \\
\hline & PNS/ASN & 16 & $8.9 \%$ \\
\hline & Karyawan Swasta & 83 & $46.1 \%$ \\
\hline & TNI/POLRI & 1 & $0.6 \%$ \\
\hline & Pelajar/Mahasiswa & 39 & $21.7 \%$ \\
\hline & Lain-lain & 23 & $12.8 \%$ \\
\hline \multirow[t]{4}{*}{ Penghasilan } & $<\operatorname{Rp} 3,000,000$ & 54 & $30 \%$ \\
\hline & $>\operatorname{Rp} 3,000,000-\operatorname{Rp} 5,000,000$ & 49 & $27 \%$ \\
\hline & $>\operatorname{Rp} 5,000,000-\operatorname{Rp} 10,000,000$ & 49 & $27 \%$ \\
\hline & $>\operatorname{Rp} 10,000,000$ & 28 & $16 \%$ \\
\hline \multirow{3}{*}{$\begin{array}{l}\text { Lama Menggunakan } \\
\text { Kitabisa.com }\end{array}$} & $<1$ tahun & 88 & $49 \%$ \\
\hline & $1-3$ tahun & 75 & $42 \%$ \\
\hline & $>3$ tahun & 17 & $9 \%$ \\
\hline \multirow{3}{*}{$\begin{array}{l}\text { Lama Menggunakan } \\
\text { Kitabisa.com sebagai } \\
\text { Muzaki }\end{array}$} & $<1$ tahun & 123 & $68 \%$ \\
\hline & $1-3$ tahun & 52 & $29 \%$ \\
\hline & $>3$ tahun & 5 & $3 \%$ \\
\hline \multirow{3}{*}{$\begin{array}{l}\text { Intensitas Membayar } \\
\text { Zakat di Kitabisa.com } \\
\text { Selama Setahun }\end{array}$} & 1 kali & 44 & $24 \%$ \\
\hline & $1-3$ kali & 53 & $29 \%$ \\
\hline & $>3$ kali & 83 & $46 \%$ \\
\hline
\end{tabular}

Sumber: Data primer, 2020 (diolah) 
Hasil karakteristik responden berdasarkan usia menunjukkan bahwa dari 180 responden pada penelitian ini sebagian besar dalam rentang usia 21-25 tahun dan 26-30 tahun. Sedangkan usia > 50 tahun menjadi kebalikannya yaitu tidak ada satupun dalam penelitian ini. Hal ini menunjukkan bahwa mayoritas pengguna zakat digital pada Kitabisa.com yaitu generasi milenial yang lebih terbiasa menggunakan sistem teknologi informasi. Selain itu, mayoritas pengguna zakat digital Kitabisa.com memiliki tingkat pendidikan S1. Sedangkan sebanyak 1\% dari 180 responden pada lain-lain yaitu diisi oleh 2 responden dengan tingkat pendidikan profesi dokter dan D1.

Hasil karakteristik responden berdasarkan pekerjaan menunjukkan bahwa mayoritas responden bekerja sebagai karyawan swasta sebesar $46 \%$. Sedangkan $1 \%$ bekerja sebagai abdi negara yaitu TNI/POLRI. Selanjutnya diikuti oleh pelajar atau mahasiswa sebesar $22 \%$ dan sebanyak $13 \%$ pada pekerjaan lainnya yaitu seperti profesi dosen, dokter, koas, freelancer, pegawai BUMN, dan Ibu Rumah Tangga.

Perbedaan besaran persentase dari segi penghasilan perbulan responden tidak berbeda jauh. Dari 180 responden, mayoritas berpenghasilan sebulan sebesar < Rp 3,000,000 dengan persentase 30\%. Selanjutnya terdapat besaran persentase yang sama pada rentang penghasilan perbulan $>\mathrm{Rp}$ $3,000,000-\operatorname{Rp~5,000,000~dan~>~Rp~5,000,000~-~Rp~10,000,000~yaitu~27\% .~Pada~rentang~penghasilan~}$ perbulan > Rp 10,000,000 sebanyak 16\%. Hasil tersebut menunjukkan bahwa besar kecilnya penghasilan tidak menjadi alasan untuk tidak menggunakan layanan zakat digital pada Kitabisa.com.

Hasil karakteristik responden berdasarkan lama menggunakan Kitabisa.com menunjukkan bahwa mayoritas responden telah menggunakan layanan Kitabisa.com $<1$ tahun sebanyak 49\%. Sedangkan karakteristik responden yang menggunakan layanan zakat digital Kitabisa.com selama $<1$ tahun sebanyak 68\%. Minimnya pengguna yang telah menikmati layanan zakat digital Kitabisa.com > 3 tahun dikarenakan tahun tersebut bertepatan dengan peluncuran tahun pertama layanan zakat digital Kitabisa.com yang bekerjasama dengan Badan Amil Zakat Nasional (BAZNAS). Sehingga pengguna layanan tersebut belum sebanyak tahun setelahnya. Intensitas pembayaran zakat via Kitabisa.com selama setahun > 3 kali mayoritas dilakukan oleh responden dengan pekerjaan sebagai karyawan swasta. Maka dapat disimpulkan bahwa penggunaan layanan zakat digital Kitabisa.com untuk membayar zakat profesi setiap bulannya.

\section{Uji Validitas dan Reabilitas Instrumen}

Uji coba instrumen penelitian dilakukan dengan jumlah sampel sebanyak 30 responden. Berdasarkan jumlah sampel tersebut diperoleh nilai $R$ tabel sebesar 0.361 pada taraf signifikansi 0.05 yang akan dibandingkan dengan $\mathrm{R}$ hitung masing-masing indikator.

Hasil pada Tabel 3 menunjukkan hasil nilai $\mathrm{R}$ hitung seluruh indikator > nilai $\mathrm{R}$ tabel, maka dapat dikatakan seluruh indikator penelitian valid dalam mengukur konstruk laten. Pada uji reliabilitas menggunakan Cronbach's alpha dengan ketentuan nilai Cronbach's alpha >0.6. Oleh karenanya, dapat dinyatakan bahwa seluruh konstruk pada penelitian ini reliabel. 
Tabel 3 Uji Validitas dan realibilitas instrumen

\begin{tabular}{|c|c|c|c|c|c|c|}
\hline Variabel & Indikator & $\begin{array}{c}\text { Interval Corrected } \\
\text { Item - Total } \\
\text { Correlation }\end{array}$ & $\begin{array}{c}R \\
\text { tabel }\end{array}$ & Validitas & $\begin{array}{c}\text { Cronbach's } \\
\text { Alpha }\end{array}$ & Reliabilitas \\
\hline Kemudahan & Kemudahan1 & 0.882 & 0.361 & Valid & \multirow{4}{*}{0.845} & \multirow{4}{*}{ Reliabel } \\
\hline \multirow[t]{3}{*}{ Penggunaan } & Kemudahan2 & 0.843 & 0.361 & Valid & & \\
\hline & Kemudahan3 & 0.772 & 0.361 & Valid & & \\
\hline & Kemudahan4 & 0.822 & 0.361 & Valid & & \\
\hline Kontrol & Kontrol1 & 0.752 & 0.361 & Valid & \multirow{3}{*}{0.817} & \multirow{3}{*}{ Reliabel } \\
\hline \multirow[t]{2}{*}{ Perilaku } & Kontrol2 & 0.937 & 0.361 & Valid & & \\
\hline & Kontrol3 & 0.870 & 0.361 & Valid & & \\
\hline Norma & Norma1 & 0.943 & 0.361 & Valid & \multirow{3}{*}{0.898} & \multirow{3}{*}{ Reliabel } \\
\hline \multirow[t]{2}{*}{ Subjektif } & Norma2 & 0.949 & 0.361 & Valid & & \\
\hline & Norma3 & 0.838 & 0.361 & Valid & & \\
\hline \multirow[t]{4}{*}{ Kegunaan } & Kegunaan1 & 0.801 & 0.361 & Valid & \multirow{4}{*}{0.863} & \multirow{4}{*}{ Reliabel } \\
\hline & Kegunaan2 & 0.871 & 0.361 & Valid & & \\
\hline & Kegunaan3 & 0.879 & 0.361 & Valid & & \\
\hline & Kegunaan4 & 0.841 & 0.361 & Valid & & \\
\hline \multirow[t]{4}{*}{ Sikap } & Sikap1 & 0.796 & 0.361 & Valid & \multirow{4}{*}{0.813} & \multirow{4}{*}{ Reliabel } \\
\hline & Sikap2 & 0.793 & 0.361 & Valid & & \\
\hline & Sikap3 & 0.836 & 0.361 & Valid & & \\
\hline & Sikap4 & 0.779 & 0.361 & Valid & & \\
\hline \multirow[t]{4}{*}{ Minat } & Minat1 & 0.884 & 0.361 & Valid & \multirow{4}{*}{0.889} & \multirow{4}{*}{ Reliabel } \\
\hline & Minat2 & 0.893 & 0.361 & Valid & & \\
\hline & Minat3 & 0.883 & 0.361 & Valid & & \\
\hline & Minat4 & 0.830 & 0.361 & Valid & & \\
\hline
\end{tabular}

Sumber: Data primer, 2020 (diolah)

\section{Analisis Outer Model (Model Pengukuran)}

Adapun pada evaluasi model pengukuran reflektif yang terdiri dari convergent validity, discriminant validity, composite reliability, average variance extracted (AVE), dan Cronbach's alpha (Haryono, 2017).

\section{Validitas konvergen}

Pengujian convergent validity dilakukan dengan melihat nilai loading factor pada tiap indikator $\geq 0.7$ yaitu dinyatakan indikator tersebut ideal. Dengan demikian, indikator tersebut valid dalam mengukur konstruk yang dibentuknya. Adapun hasil uji validitas konvergen pada model penelitian ini, sebagai berikut: 
Tabel 4 Uji validitas konvergen

\begin{tabular}{|c|c|c|c|}
\hline Konstruk & Indikator & $\begin{array}{c}\text { Outer } \\
\text { Loading }\end{array}$ & Keterangan \\
\hline \multirow[t]{4}{*}{ Kegunaan } & Kegunaan1 & 0.783 & Valid \\
\hline & Kegunaan2 & 0.851 & Valid \\
\hline & Kegunaan3 & 0.791 & Valid \\
\hline & Kegunaan4 & 0.733 & Valid \\
\hline \multirow[t]{4}{*}{ Kemudahan } & Kemudahan 1 & 0.869 & Valid \\
\hline & Kemudahan2 & 0.881 & Valid \\
\hline & Kemudahan3 & 0.812 & Valid \\
\hline & Kemudahan4 & 0.733 & Valid \\
\hline \multirow[t]{4}{*}{ Sikap } & Sikap1 & 0.835 & Valid \\
\hline & Sikap2 & 0.839 & Valid \\
\hline & Sikap3 & 0.874 & Valid \\
\hline & Sikap4 & 0.758 & Valid \\
\hline \multirow[t]{3}{*}{ Norma } & Norma1 & 0.913 & Valid \\
\hline & Norma2 & 0.888 & Valid \\
\hline & Norma3 & 0.898 & Valid \\
\hline \multirow[t]{3}{*}{ Kontrol } & Kontrol1 & 0.791 & Valid \\
\hline & Kontrol2 & 0.808 & Valid \\
\hline & Kontrol3 & 0.792 & Valid \\
\hline \multirow[t]{4}{*}{ Minat } & Minat1 & 0.913 & Valid \\
\hline & Minat2 & 0.927 & Valid \\
\hline & Minat3 & 0.918 & Valid \\
\hline & Minat4 & 0.864 & Valid \\
\hline
\end{tabular}

Sumber: Data primer, 2020 (diolah)

Berdasarkan Tabel 4, pada tahap uji model pengukuran menunjukkan bahwa seluruh indikator dari konstruk model penelitian ini memiliki nilai loading factor $\geq 0.70$. Maka dapat dikatakan telah memenuhi syarat uji validitas konvergen. Oleh karenanya, setiap indikator mempunyai validitas yang baik atau fit model.

\section{Validitas diskriminan}

Validitas diskriminan merupakan pengujian untuk memastikan bahwa tiap-tiap variabel laten berbeda dengan variabel laten lainnya. Kriteria uji validitas diskriminan yaitu ukuran cross loading factor dengan membandingkan nilainya pada konstruk yang dituju harus lebih besar dari konstruk lain. Berikut hasil uji validitas diskriminan pada model penelitian ini: 
Tabel 5 Uji diskriminan variabel penelitian

\begin{tabular}{lccccccc}
\hline & Kegunaan & $\begin{array}{c}\text { Kemudahan } \\
\text { Penggunaan }\end{array}$ & $\begin{array}{c}\text { Kontrol } \\
\text { Perilaku }\end{array}$ & Minat & $\begin{array}{c}\text { Norma } \\
\text { Subjektif }\end{array}$ & Sikap & Ket. \\
\hline Kegunaan1 & 0.8 & 0.5 & 0.5 & 0.4 & -0 & 0.5 & Valid \\
Kegunaan2 & 0.9 & 0.6 & 0.6 & 0.5 & 0 & 0.6 & Valid \\
Kegunaan3 & 0.8 & 0.6 & 0.6 & 0.5 & 0.1 & 0.6 & Valid \\
Kegunaan4 & 0.7 & 0.4 & 0.4 & 0.5 & 0.1 & 0.6 & Valid \\
Kemudahan1 & 0.5 & 0.9 & 0.5 & 0.5 & 0.2 & 0.6 & Valid \\
Kemudahan2 & 0.5 & 0.9 & 0.4 & 0.5 & 0.2 & 0.6 & Valid \\
Kemudahan3 & 0.6 & 0.8 & 0.5 & 0.5 & 0.1 & 0.6 & Valid \\
Kemudahan4 & 0.6 & 0.7 & 0.4 & 0.5 & 0.1 & 0.5 & Valid \\
Kontrol1 & 0.6 & 0.6 & 0.8 & 0.5 & -0 & 0.5 & Valid \\
Kontrol2 & 0.5 & 0.4 & 0.8 & 0.5 & 0.1 & 0.5 & Valid \\
Kontrol3 & 0.5 & 0.4 & 0.8 & 0.4 & 0.1 & 0.4 & Valid \\
Minat1 & 0.6 & 0.6 & 0.6 & 0.9 & 0.2 & 0.7 & Valid \\
Minat2 & 0.6 & 0.6 & 0.6 & 0.9 & 0.2 & 0.6 & Valid \\
Minat3 & 0.5 & 0.5 & 0.5 & 0.9 & 0.2 & 0.6 & Valid \\
Minat4 & 0.5 & 0.5 & 0.5 & 0.9 & 0.2 & 0.6 & Valid \\
Norma1 & 0.1 & 0.2 & 0.1 & 0.2 & 0.9 & 0.1 & Valid \\
Norma2 & -0 & 0.1 & 0 & 0.1 & 0.9 & 0 & Valid \\
Norma3 & 0 & 0.1 & 0.1 & 0.2 & 0.9 & 0.1 & Valid \\
Sikap1 & 0.6 & 0.6 & 0.5 & 0.6 & 0.1 & 0.8 & Valid \\
Sikap2 & 0.6 & 0.5 & 0.5 & 0.5 & -0 & 0.8 & Valid \\
Sikap3 & 0.7 & 0.7 & 0.6 & 0.7 & 0.2 & 0.9 & Valid \\
Sikap4 & 0.5 & 0.4 & 0.4 & 0.6 & 0 & 0.8 & Valid \\
\hline Sumbr Data & $2020(610$ & & & & & &
\end{tabular}

Sumber: Data primer, 2020 (diolah)

Tabel 5 menunjukkan bahwa seluruh konstruk telah sesuai dengan kriteria uji yaitu cross loading factor tiap konstruk lebih besar daripada konstruk lainnya. Sehingga, dapat dikatakan bahwa setiap konstruk berbeda dengan konstruk lainnya.

\section{Average Variance Extracted (AVE) dan Cronbach's alpha}

Composite reliability digunakan untuk mengetahui internal consistency reliability yaitu dengan syarat mempunyai reliabilitas yang tinggi bahwa nilai batas $\geq 0.7$ dapat diterima, dan nilai $\geq 0.8$ sangat memuaskan. Selain itu, adapula Cronbach's alpha untuk mengetahui reliabilitas pada suatu konstruk dengan mensyaratkan nilai > 0.7 untuk semua konstruk. Sedangkan, Average Variance Extracted (AVE) menggambarkan besaran keragaman atau varian variabel teramati yang dapat dimiliki oleh variabel laten. Kriteria dalam menilai AVE yaitu minimal 0.5. Artinya variabel laten dapat menggambarkan rata-rata lebih dari setengah varian dari indikator-indikatornya. Adapun hasil pengujian reliabilitas konstruk penelitian ini, yaitu:

Hasil uji reliabilitas pada Tabel 6 menunjukkan bahwa seluruh konstruk memiliki nilai Cronbach's alpha $>0,7$, sedangkan composite reliability bernilai > 0.7, dan AVE memiliki nilai $>0.5$. Oleh karenanya seluruh uji reliabilitas telah sesuai kriteria hasil uji, maka dapat dikatakan bahwa seluruh konstruk memiliki reliabilitas yang baik. 
Tabel 6 Uji reliabilitas konstruk penelitian

\begin{tabular}{lcccc}
\hline & Cronbach's Alpha & Composite reliability & AVE & Keterangan \\
\hline Kegunaan & 0.799 & 0.869 & 0.625 & Reliabel \\
Kemudahan & 0.843 & 0.895 & 0.683 & Reliabel \\
Kontrol & 0.715 & 0.839 & 0.635 & Reliabel \\
Minat & 0.927 & 0.948 & 0.820 & Reliabel \\
Norma & 0.888 & 0.927 & 0.810 & Reliabel \\
Sikap & 0.846 & 0.897 & 0.685 & Reliabel \\
\hline
\end{tabular}

Sumber: Data primer, 2020 (diolah)

\section{Analisis Inner Model (Model Struktural)}

\section{F Square}

Pada analisis SEM, besaran $f$ square $\left(\mathrm{f}^{2}\right)$ menunjukkan seberapa besar pengaruh secara parsial masingmasing variabel laten eksogen terhadap variabel laten endogen (Haryono, 2017). Menurut Cohen, nilai $f$ square sebesar 0.02 termasuk ke dalam kategori berpengaruh kecil. Kemudian jika nilai $\mathrm{f}$ square sebesar 0.15 termasuk ke dalam kategori berpengaruh menegah atau medium. Pada nilai $f$ square sebesar 0.35 termasuk ke dalam kategori berpengaruh besar (Ghozali dan Latan, 2015). Adapun di bawah ini nilai $f$ square variabel laten eksogen terhadap variabel laten endogen:

\begin{tabular}{lccc}
\multicolumn{4}{c}{ Tabel 7 Uji $f$ square } \\
\hline & Kegunaan & Minat & Sikap \\
\hline Kegunaan & & 0.000 & 0.317 \\
Kemudahan & 0.830 & 0.023 & 0.170 \\
Kontrol & & 0.074 & \\
Norma & 0.047 & \\
Sikap & 0.186 \\
\hline \multicolumn{3}{l}{ Sumber: Data primer, 2020 (diolah) }
\end{tabular}

\section{R Square}

$R$ Square bertujuan untuk menunjukkan seberapa besar kontribusi variabel laten eksogen mampu menjelaskan variabel laten endogen. Kemudian, berdasarkan nilai $R$ Square dapat menunjukkan kekuatan model SEM. Nilai $R$ Square sebesar 0.75 menunjukkan bahwa pada tingkat kategori kekuatan model tinggi. Nilai $R$ Square sebesar 0.50 menunjukkan pada tingkat kategori kekuatan model moderate dan nilai $R$ Square sebesar 0.25 menunjukkan model lemah (Ghozali dan Latan, 2015). Adapun hasil nilai $R$ Square pada model penelitian ini, yaitu:

Tabel 8 Uji $R$ square

\begin{tabular}{lcc}
\hline & R Square & Keterangan \\
\hline Kegunaan & 0.454 & Moderate \\
Minat & 0.589 & Moderate \\
Sikap & 0.594 & Moderate \\
\hline Sumber: Data primer, 2020 (diolah) &
\end{tabular}

Hasil tersebut menunjukkan bahwa kontribusi yang diberikan variabel persepsi kemudahan penggunaan sebesar $45.4 \%$ dalam menerangkan persepsi kegunaan, sisanya dipengaruhi oleh variabel atau faktor lain sebesar 54.6\%. Sedangkan besar kontribusi yang diberikan variabel persepsi kegunaan, persepsi kemudahan penggunaan, norma subjektif, persepsi kontrol perilaku, dan sikap sebesar 58.9\% dalam menerangkan minat penggunaan layanan zakat digital Kitabisa.com, sisanya dipengaruhi oleh variabel atau faktor lain sebesar $41.1 \%$. Selain itu, besar kontribusi yang diberikan 
variabel persepsi kegunaan dan persepsi kemudahan penggunaan sebesar 59.4\%, sisanya dipengaruhi oleh variabel atau faktor lain sebesar $40.6 \%$.

\section{Uji Signifikansi}

Uji Bootstrapping dilakukan untuk mengetahui nilai signifikansi untuk melihat pengaruh antara variabel yang dilakukan. Ghozali dan Latan (2015) menggunakan prosedur bootstrap dengan seluruh sampel asli untuk melakukan resampling. Tingkat signifikan pada bootstrapping yaitu 0.05. Adapun hasil bootstrap pada penelitian ini terdapat pada Gambar 6. Hasil estimasi model SEM pada penelitian ini akan digunakan untuk pengujian hipotesis.

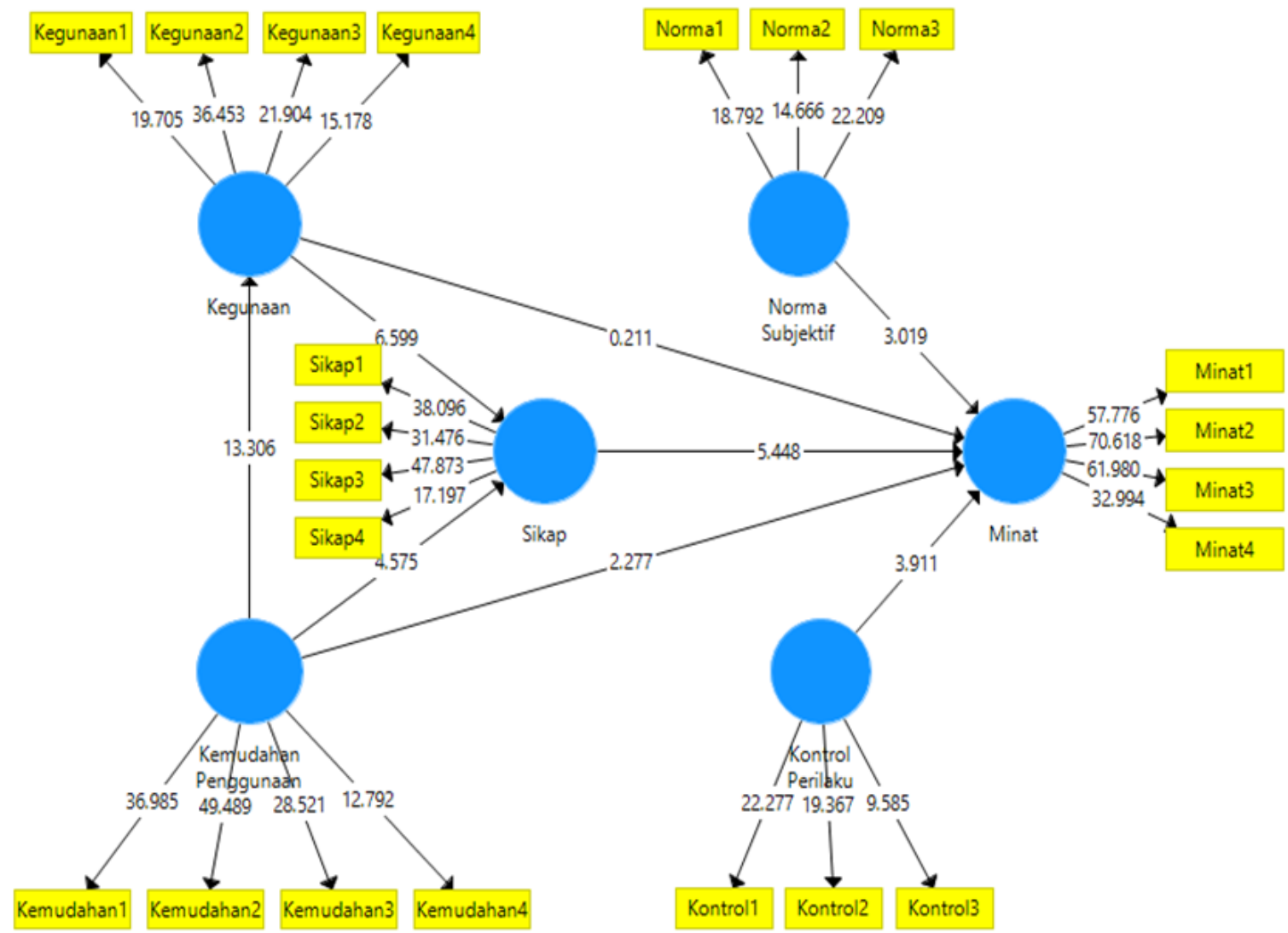

Sumber: Data primer, 2020 (diolah)

Gambar 6 Hasil uji bootstrap model SEM

\section{Pengujian Hipotesis}

Pada tahap terakhir penelitian menggunakan metode SEM untuk mengetahui sejauh mana variabel laten eksogen atau independen memengaruhi variabel laten endogen atau dependen. Untuk mengetahui hal itu, dilakukan pengujian hipotesis sebagai tahap pengambilan keputusan dalam penelitian ini. Adapun ketentuan kriteria yang digunakan dalam pengujian hidpotesis yaitu:

\section{Hipotesis}

$\mathrm{H}_{0}$ : Variabel laten eksogen secara parsial tidak berpengaruh terhadap variabel laten endogen $\mathrm{H}_{\mathrm{a}}$ : Variabel laten eksogen secara parsial berpengaruh terhadap variabel laten endogen

\section{Kriteria pengujian hipotesis}

Jika t hitung $\geq 1.96$ atau $\mathrm{p}$ hitung atau $\mathrm{p} \leq 0.05$, maka $\mathrm{H}_{0}$ ditolak dan $\mathrm{H}_{\mathrm{a}}$ diterima Jika t hitung $\leq 1.96$, atau $\mathrm{p}$ hitung atau $\mathrm{p} \geq 0.05$, maka $\mathrm{H}_{0}$ diterima dan $\mathrm{H}_{\mathrm{a}}$ ditolak Adapun hasil uji hipotesis pada penelitian ini dapat dilihat pada tabel sebagai berikut: 
Tabel 9 Hasil uji hipotesis

\begin{tabular}{|c|c|c|c|c|}
\hline No & Hipotesis & T Statistik & P Values & Kesimpulan \\
\hline 1. & $\begin{array}{l}\text { Persepsi Kemudahan Penggunaan } \\
\text { berpengaruh signifikan terhadap } \\
\text { Persepsi Kegunaan }\end{array}$ & 13.306 & 0.000 & Diterima \\
\hline 2. & $\begin{array}{l}\text { Persepsi Kegunaan berpengaruh } \\
\text { signifikan terhadap Sikap }\end{array}$ & 6.599 & 0.000 & Diterima \\
\hline 3. & $\begin{array}{l}\text { Persepsi Kemudahan Penggunaan } \\
\text { berpengaruh signifikan terhadap } \\
\text { Sikap }\end{array}$ & 4.575 & 0.000 & Diterima \\
\hline 4. & $\begin{array}{l}\text { Persepsi Kegunaan berpengaruh } \\
\text { signifikan terhadap Minat }\end{array}$ & 0.211 & 0.833 & Ditolak \\
\hline 5. & $\begin{array}{l}\text { Persepsi Kemudahan Penggunaan } \\
\text { berpengaruh signifikan terhadap } \\
\text { Minat }\end{array}$ & 2.277 & 0.023 & Diterima \\
\hline 6. & $\begin{array}{l}\text { Norma Subjektif berpengaruh } \\
\text { signifikan terhadap Minat }\end{array}$ & 3.019 & 0.003 & Diterima \\
\hline 7. & $\begin{array}{l}\text { Persepsi Kontrol Perilaku } \\
\text { berpengaruh signifikan terhadap } \\
\text { Minat }\end{array}$ & 3.911 & 0.000 & Diterima \\
\hline 8. & $\begin{array}{l}\text { Sikap pengguna berpengaruh } \\
\text { signifikan terhadap Minat }\end{array}$ & 5.448 & 0.000 & Diterima \\
\hline
\end{tabular}

Sumber: Data primer, 2020 (diolah)

\section{Pengaruh Persepsi Kemudahan Penggunaan (Perceived Ease of Use) terhadap Persepsi Kegunaan (Perceived Usefulness)}

Berdasarkan hasil uji hipotesis melalui uji hipotesis menunjukkan nilai t hitung sebesar 13.306 dengan taraf signifikansi 0.000 . Hasil tersebut telah memenuhi kriteria hipotesis yaitu nilai $13.306 \geq 1.96$ dan taraf signifikansi $0.000 \leq 0.05$. Maka $\mathrm{H}_{0}$ berhasil ditolak dan $\mathrm{H}_{1}$ diterima. Hasil pengujian Hipotesis 1 atau $\mathrm{H}_{1}$ membuktikan bahwa persepsi kemudahan penggunaan berpengaruh signifikan terhadap persepsi kegunaan. Oleh karena itu, dapat dikatakan bahwa semakin tinggi persepsi masyarakat terhadap kemudahan penggunaan layanan zakat digital Kitabisa.com, maka semakin tinggi pula persepsi masyarakat terhadap kegunaan layanan zakat digital Kitabisa.com.

Hasil hipotesis ini sejalan dengan penelitian Amalia (2018), Indrayana et al. (2016), dan Thaker et al. (2018) yang membuktikan bahwa persepsi kemudahan penggunaan memiliki pengaruh signifikan terhadap persepsi kegunaan. Menurut Davis et al. (1989) persepsi kemudahan penggunaan dapat memengaruhi persepsi kegunaan karena kemudahan suatu sistem teknologi informasi yang dirasakan pengguna dapat meningkatkan performa kinerjanya. Hal ini karena tidak butuh waktu yang lama untuk menggunakan sistem tersebut.

\section{Pengaruh Persepsi Kegunaan terhadap Sikap (Attitude)}

Hasil pengujian pada persepsi kegunaan terhadap sikap menunjukkan nilai t hitung sebesar $6.599 \geq$ 1.96 pada taraf signifikansi $0.000 \leq 0.05$. Berdasarkan hal tersebut menunjukkan bahwa hasil pengujian telah memenuhi kriteria uji hipotesis. Dapat disimpulkan bahwa $\mathrm{H}_{0}$ ditolak dan $\mathrm{H}_{2}$ diterima, maka hal ini dinyatakan perspektif kegunaan berpengaruh signifikan terhadap sikap. Oleh karena itu, dapat dikatakan bahwa semakin tinggi persepsi masyarakat terhadap kegunaan layanan zakat digital Kitabisa.com maka, semakin tinggi pula masyarakat dalam menyikapi layanan zakat digital Kitabisa.com.

Hal ini sejalan dengan penelitian Celik dan Yilmaz (2011), Indrayana et al. (2016), dan Amalia (2018) yang menjelaskan bahwa perspektif kegunaan berpengaruh signifikan terhadap sikap penggunaan suatu sistem. Davis et al. (1989) menjelaskan bahwa kegunaan suatu sistem akan diakui 
oleh pengguna jika memberikan manfaat sehingga diharapkan dapat meningkatkan kinerjanya. Berdasarkan hasil penelitian tersebut dapat diasumsikan bahwa menurut perspektif responden penggunaan layanan zakat digital Kitabisa.com berguna bagi mereka sehingga dapat memengaruhi sikap responden untuk menggunakannya sebagai salah satu metode pembayaran zakat secara online yang mereka sukai.

\section{Pengaruh Persepsi Kemudahan Penggunaan (Perceived Ease of Use) terhadap Sikap (Attitude)}

Pada hasil pengujian hipotesis persepsi kemudahan penggunaan terhadap sikap menunjukkan hasil yaitu nilai t hitung $4.575 \geq 1.96$ dan taraf signifikansi $0.000 \leq 0.05$. Berdasarkan hal tersebut, maka $\mathrm{H}_{0}$ berhasil ditolak dan $\mathrm{H}_{3}$ diterima. Oleh karena itu, dapat dinyatakan bahwa persepsi kemudahan penggunaan berpengaruh signifikan terhadap sikap. Hasil uji hipotesis tersebut menunjukkan bahwa semakin tinggi persepsi masyarakat terhadap kemudahan penggunaan layanan zakat digital Kitabisa.com maka, semakin tinggi pula masyarakat dalam menyikapi layanan zakat digital Kitabisa.com.

Hasil penelitian ini didukung oleh Indrayana et al. (2016) dan Amalia (2018) dengan menunjukkan hasil yang sama yaitu perspektif kemudahan penggunaan berpengaruh signifikan terhadap sikap pengguna untuk menggunakan suatu sistem. Menurut Indrayana et al. (2016), fitur-fitur yang mudah digunakan akan memengaruhi pengguna untuk menggunakan suatu sistem.

Kesesuaian hasil penelitian ini dengan teori yang telah dibangun oleh Davis et al. (1989) yaitu dengan mengidentifikasikan dua keyakinan sikap yaitu perspektif kegunaan dan perspektif kemudahan penggunaan. Perspektif kemudahan penggunaan berdasarkan atas kepercayaan pengguna layanan zakat digital Kitabisa.com bahwa tidak memerlukan banyak usaha untuk menggunakan layanan tersebut. Oleh karenanya, hal tersebut menjadi faktor yang memengaruhi sikap pengguna seperti menyukai layanan pembayaran zakat digital Kitabisa.com.

\section{Pengaruh Persepsi Kegunaan (Perceived Usefulness) terhadap Minat (Intention to Use)}

Pada pengujian hipotesis ini yaitu variabel persepsi kegunaan terhadap variabel minat memperoleh nilai probabilitas sebesar $0.833 \geq 0.05$. Berdasarkan hasil tersebut menunjukkan bahwa tidak terpenuhinya kriteria uji hipotesis. Dapat disimpulkan bahwa $\mathrm{H}_{0}$ diterima dan $\mathrm{H}_{4}$ ditolak, artinya persepsi kegunaan tidak berpengaruh signifikan terhadap minat. Hasil tersebut menunjukkan bahwa tinggi rendahnya persepsi kegunaan layanan zakat digital Kitabisa.com tidak berpengaruh terhadap minat masyarakat untuk menggunakan layanan tersebut.

Persepsi kegunaan berkaitan erat dengan tingkat kepercayaan muzaki dalam penggunaan layanan zakat digital Kitabisa.com berguna untuk meningkatkan kinerjanya. Sedangkan pada penelitian ini menunjukkan bahwa ketiadaan pengaruh persepsi kegunaan terhadap minat menggunakan layanan zakat digital Kitabisa.com.

Peneliti menduga hal tersebut karena mayoritas responden memiliki kecenderungan untuk melakukan pembayaran zakat secara konvensional seperti pemotongan gaji secara langsung dari instansi, memberikannya melalui masjid atau menyalurkan zakatnya langsung kepada yang berhak menerimanya di lingkungan sekitar dibandingkan melalui layanan zakat digital Kitabisa.com. Hal ini disebabkan responden terbiasa dengan sistem konvensional yang sudah lama dilakukan sedangkan layanan zakat digital baru berjalan sejak pertengahan 2016. Dapat dilihat dari latar belakang responden bahwa mayoritas mulai menggunakan layanan zakat digital Kitabisa.com $<1$ tahun belakangan.

Hasil penelitian ini sejalan dengan Indrayana et al. (2016) yang menunjukkan bahwa pengaruh perspektif kegunaan aplikasi tidak signifikan terhadap minat menggunakan aplikasi tersebut untuk transaksi. Dapat simpulkan bahwa pada penelitian ini, persepsi kegunaan tidak menjadi faktor yang memengaruhi minat responden untuk menggunakan layanan zakat digital Kitabisa.com. 


\section{Pengaruh Persepsi Kemudahan Penggunaan (Perception Easy to Use) terhadap Minat (Intention to Use)}

Hasil pengujian hipotesis ini yaitu variabel persepsi kemudahan penggunaan terhadap variabel minat memperoleh nilai probabilitas sebesar $0.023 \leq 0.05$. Oleh karena itu, memenuhi kriteria hasil uji hipotesis. Maka disimpulkan bahwa $\mathrm{H}_{0}$ berhasil ditolak dan $\mathrm{H}_{5}$ diterima, dengan demikian variabel persepsi kemudahan penggunaan berpengaruh signifikan terhadap variabel minat. Hasil tersebut menunjukkan bahwa semakin tinggi persepsi masyarakat terhadap kemudahan penggunaan layanan zakat digital Kitabisa.com, maka semakin tinggi pula minat masyarakat untuk menggunakan layanan zakat digital Kitabisa.com.

Menurut Davis et al. (1989), persepsi kemudahan penggunaan merupakan tingkat keyakinan individu terhadap suatu layanan merupakan hal yang mudah, tidak memerlukan usaha yang besar untuk penggunaannya. Oleh karenanya Mahendra (2014) berpendapat bahwa persepsi kemudahan penggunaan berkaitan dengan kemampuan individu dalam mempelajari dan beradaptasi dengan sesuatu yang baru. Hal ini berkaitan dengan mudah atau tidaknya ketika menggunakan layanan digital.

Peneliti menduga adanya pengaruh persepsi kemudahan penggunaan terhadap minat menggunakan layanan zakat digital Kitabisa.com disebabkan oleh mayoritas responden memiliki tingkat pendidikan S1 dan didominasi oleh rentang usia generasi milenial. Hal tersebut menujukkan bahwa semakin tinggi tingkat pendidikan responden, maka responden cenderung memiliki kemampuan untuk memahami dan menggunakan layanan zakat digital Kitabisa.com. Dengan kata lain, responden dalam penelitian ini lebih sadar teknologi sehingga tidak memerlukan usaha yang besar untuk penggunaannya.

Pada penelitian ini dapat disimpulkan bahwa persepsi kemudahan penggunaan menjadi faktor yang memengaruhi minat responden untuk menggunakan layanan zakat digital Kitabisa.com. Hasil pengujian hipotesis ini konsisten dengan penelitian yang dilakukan oleh Duy (2012) yang menunjukkan bahwa persepsi kemudahan pengunaan berpengaruh signifikan terhadap minat untuk menggunakan suatu layanan.

\section{Pengaruh Norma Subjektif (Subjective Norms) terhadap Minat (Intention to Use)}

Hasil pengujian hipotesis ini diperoleh nilai t hitung sebesar 3.019 $\geq 1.96$ dan taraf signifikansi 0.003 $\leq 0.05$. Maka, dapat dilihat bahwa terpenuhinya kriteria uji hipotesis. Berdasarkan hal tersebut, maka $\mathrm{H}_{0}$ berhasil ditolak dan $\mathrm{H}_{6}$ diterima. Oleh karenanya, hal ini dinyatakan bahwa norma subjektif berpengaruh signifikan terhadap minat. Hasil tersebut menunjukkan bahwa semakin tinggi norma subjektif terhadap layanan zakat digital Kitabisa.com, maka semakin tinggi minat masyarakat untuk menggunakan layanan tersebut.

Berdasarkan hasil tersebut, maka pada penelitian ini variabel norma subjektif termasuk ke dalam faktor-faktor yang memengaruhi minat untuk menggunakan layanan zakat digital Kitabisa.com. Hasil penelitian ini sejalan dengan (Indrayana et al., 2016) yang menunjukkan bahwa norma subjektif berpengaruh signifikan terhadap minat untuk menggunakan sebuah sistem.

Hal tersebut disebabkan norma subjektif erat kaitannya dengan faktor eksternal atau sosial. Sehingga dapat diasumsikan bahwa responden berminat menggunakan layanan zakat Kitabisa.com dipengaruhi oleh faktor eksternal, walaupun sebagian responden tidak mempertimbangan pandangan orang-orang sekitar terkait layanan tersebut.

\section{Pengaruh Persepsi Kontrol Perilaku (Perceived Control Behavior) terhadap Minat (Intention to Use)}

Berdasarkan hasil uji hipotesis melalui uji hipotesis dengan t hitung sebesar $3.911 \geq 1.96$ dengan taraf signifikansi $0.000 \leq 0.05$. Maka, $\mathrm{H}_{0}$ berhasil ditolak dan $\mathrm{H}_{7}$ diterima. Hasil pengujian Hipotesis 7 atau 
$\mathrm{H}_{7}$ membuktikan bahwa persepsi kontrol perilaku berpengaruh signifikan terhadap minat. Hal ini menunjukkan bahwa semakin tinggi persepsi kontrol perilaku maka semakin tinggi minat masyarat untuk menggunakan layanan zakat digital Kitabisa.com.

Hasil ini konsisten dengan penelitian terdahulu yaitu Mahendra (2014) yang menunjukkan bahwa persepsi kontrol perilaku berpengaruh signifikan terhadap minat untuk menggunakan sebuah sistem. Menurut Hamzah dalam Mahendra (2014), kontrol perilaku berkaitan erat dengan kesesuaian pendidikan, kemampuan atau kompetensi individu, pengalaman menggunakan suatu sistem, kemudahan yang dirasakan pada saat pembelajaran sesuatu yang baru atau adaptasi terhadap hal baru. Salah satunya yaitu latar belakang pendidikan responden.

Berdasarkan hal tersebut, pada penelitian ini, latar belakang pendidikan mayoritas responden yaitu S1 sebesar 57\%. Maka dapat dikatakan bahwa semakin tinggi tingkat pendidikan responden terdapat kecenderungan responden memiliki kemampuan dan pengetahuan terkait penggunaan layanan zakat digital Kitabisa.com. Selain itu, mayoritas responden bekerja sebagai karyawan, pengusaha dan profesi lainnya, dengan demikian adanya sumber daya berupa dana zakat. Sehingga pada penelitian ini, latar belakang pendidikan berperan dalam memengaruhi minat untuk menggunakan layanan zakat digital Kitabisa.com dan didukung dengan kepemilikan sumber daya berupa dana zakat yang harus disalurkan. Sehingga hasil penelitian ini menunjukkan bahwa kontrol perilaku termasuk ke dalam faktor-faktor yang berpengaruh signifikan terhadap minat untuk menggunakan layanan zakat digital Kitabisa.com.

\section{Pengaruh Sikap (Attitude) terhadap Minat (Intention to Use)}

Pada pengujian hipotesis pada variabel sikap terhadap minat menunjukkan nilai t hitung sebesar 5.448 dengan taraf signifikansi 0.000 . Hasil tersebut telah memenuhi kriteria hipotesis yaitu nilai t hitung $5.448 \geq 1.96$ dan taraf signifikansi $0.000 \leq 0.05$. Berdasarkan hal tersebut, maka $\mathrm{H}_{0}$ berhasil ditolak dan $\mathrm{H}_{8}$ diterima. Oleh karena itu, dapat disimpulkan bahwa sikap berpengaruh signifikan terhadap minat. Hasil penelitian ini menunjukkan bahwa semakin baik sikap pengguna layanan zakat digital Kitabisa.com maka semakin tinggi minat masyarakat untuk menggunakan layanan tersebut.

Penelitian ini sejalan dengan hasil penelitian terdahulu yaitu Amalia (2018), Mahendra (2014) dan Suyanto dan Kurniawan (2019) yang membuktikan bahwa sikap pengguna berpengaruh signifikan terhadap minat untuk menggunakan sebuah sistem. Menurut Davis et al. (1989), attitude merupakan bentuk perasaan menyukai atau tidak atas sesuatu yang telah dilakukan. Sedangkan minat untuk menggunakan (intention to use) merupakan kecenderungan atas perilaku pengguna untuk tetap menggunakan suatu sistem teknologi informasi. Pada teori yang telah dibangun oleh Davis et al. yaitu TAM, menjelaskan bahwa sikap dapat memprediksi minat perilaku seseorang. Menurut model TAM, terdapat dua komponen yang dapat memengaruhi minat yaitu komponen kognitif ialah perspektif kegunaan dan komponen aktif ialah sikap. Oleh karena itu, sikap berupa bentuk perasaan suka atau tidak suka dapat menjadi faktor yang memengaruhi minat seseorang untuk menggunakan layanan zakat digital Kitabisa.com.

\section{Implikasi Manajerial}

Terlepas dari keterbatasan penelitian, diharapkan hasil penelitian ini dapat memberikan masukan atau saran bagi pihak manajemen Kitabisa.com maupun lembaga zakat lainnya untuk dijadikan sebagai bahan pertimbangan dalam meningkatkan kualitas layanan zakat digital dan kinerja perusahaan dalam upaya optimalisasi pengumpulan dana zakat.

Pada penelitian ini menunjukkan bahwa faktor yang dapat memengaruhi minat dalam menggunakan layanan zakat digital yaitu konstruk persepsi kemudahan penggunaan (perceived ease of use), norma subjektif (subjective norms), persepsi kontrol perilaku (perceived behavior control), dan sikap (attitude). Namun, pada penelitian ini ditemukan tidak adanya pengaruh persepsi kegunaan (perceived usefulness) terhadap minat menggunakan layanan zakat digital. Dengan kata lain, penggunaan layanan 
zakat digital masih dirasa belum dapat meningkatkan kinerja penggunanya. Sedangkan persepsi kegunaan berkaitan erat dengan tingkat kepercayaan muzaki dalam penggunaan layanan zakat digital berguna untuk meningkatkan kinerjanya. Hal tersebut dikarenakan mayoritas responden bekerja sebagai karyawan. Oleh karenanya, dapat diasumsikan bahwa responden memiliki cenderung untuk meningkatkan kinerjanya, maka melakukan pembayaran zakat secara konvensional seperti pemotongan gaji secara langsung dari instansi.

Berdasarkan hal tersebut, untuk menarik minat muzaki dalam memakai layanan zakat digital diperlukan program zakat rutin. Khususnya diperuntukkan bagi karyawan suatu perusahaan yang dipotong langsung dari rekening setiap bulannya sesuai dengan perjanjian dan ketentuan yang disepakati berbagai pihak. Seperti halnya layanan donasi rutin Kitabisa.com, layanan zakat digital juga perlu diadakan sebagai program secara rutin dengan mencontoh program yang lebih awal muncul yaitu donasi rutin Kitabisa.com. Hal ini sebagai upaya meningkatkan kinerja pengguna layanan zakat digital sehingga tidak perlu lagi untuk mengulang proses pembayaran zakat setiap bulan, namun secara praktis sudah otomatis terbayar tepat waktu melalui sistem tersebut.

Hasil penelitian juga menunjukkan bahwa adanya pengaruh norma subjektif terhadap minat menggunakan layanan zakat digital. Hal ini disebabkan sebagian responden berminat menggunakan layanan zakat Kitabisa.com karena intervensi orang lain walaupun sebagian besar lainnya tidak mempertimbangan pandangan orang-orang sekitar terkait layanan tersebut, melainkan atas kesadarannya sendiri akan perkembangan teknologi. Hal ini dapat diasumsikan pengguna layanan zakat kurang turut serta mengajak orang sekelilingnya menggunakan layanan tersebut. Oleh karena itu, perusahaan perlu melakukan promosi layanan zakat di berbagai sosial media dengan menunjukkan keunggulan dari penggunaan layanan zakat digital seperti tidak dikenakan biaya administrasi atau $0 \%$ administrasi sebagai upaya penyebarluasan info layanan zakat sekaligus memperbanyak muzaki yang menggunakan layanan zakat digital sehingga semakin banyak pula dana zakat yang terkumpul.

Selain itu, pada fitur layanan zakat perusahaan perlu mempermudah penjelasan terkait tata cara penggunaan layanan zakat. Tak hanya menampilkan fitur salurkan zakat dan kalkulator zakat. Hal ini guna mempermudah pengguna, khususnya pengguna baru untuk memahami penggunaan layanan zakat digital. Perusahaan memberikan edukasi mengenai zakat khususnya cara perhitungan dan pembayaran melalui layanan zakat digital tersebut. Hal ini sebagai upaya meningkatkan minat menggunakan layanan zakat sekaligus memberikan pengetahuan terkait tata cara dalam menggunakan layanan tersebut.

\section{SIMPULAN}

Hasil penelitian menunjukkan bahwa minat untuk menggunakan (intention to use) layanan zakat digital Kitabisa.com secara signifikan dipengaruhi oleh persepsi kemudahan penggunaan (perceived ease of use), norma subjektif (subjective norms), persepsi kontrol perilaku (perceived behavior control), dan sikap (attitude). Namun, pada penelitian ini ditemukan tidak adanya pengaruh persepsi kegunaan (perceived usefulness) terhadap minat menggunakan layanan zakat digital. Dengan kata lain, penggunaan layanan zakat digital masih dirasa belum dapat meningkatkan kinerja penggunanya.

Hal tersebut disebabkan mayoritas responden bekerja sebagai karyawan. Oleh karenanya dapat diasumsikan bahwa responden memiliki kecenderungan untuk meningkatkan kinerjanya, maka melakukan pembayaran zakat secara konvensional seperti pemotongan gaji secara langsung dari instansi. Berdasarkan hal tersebut, guna menarik minat muzaki untuk memakai layanan zakat digital diperlukan program zakat rutin. Khususnya diperuntukkan bagi karyawan suatu perusahaan yang dipotong langsung dari rekening setiap bulannya sesuai dengan perjanjian dan ketentuan yang disepakati berbagai pihak. 
Variabel persepsi kemudahan penggunaan (perceived ease of use) berpengaruh signifikan terhadap variabel persepsi kegunaan (perceived usefullness). Variabel persepsi kegunaan (perceived usefullness) berpengaruh signifikan terhadap variabel sikap (attitude). Hasil yang sama ditunjukkan oleh variabel persepsi kemudahan penggunaan (perceived ease of use) berpengaruh signifikan terhadap variabel sikap (attitude).

Variabel norma subjektif (subjective noms) berpengaruh signifikan terhadap minat untuk menggunakan (intention to use). Hal ini disebabkan beberapa responden berminat menggunakan layanan zakat Kitabisa.com karena intervensi orang lain walaupun beberapa lainnya tidak mempertimbangan pandangan orang-orang sekitar terkait layanan tersebut, melainkan atas kesadarannya sendiri akan perkembangan teknologi. Dapat diasumsikan pengguna layanan zakat kurang turut serta mengajak orang sekelilingnya menggunakan layanan tersebut. Perusahaan perlu melakukan promosi layanan zakat di berbagai sosial media dengan menunjukkan keunggulan dari penggunaan layanan zakat digital seperti tidak dikenakan biaya administrasi sebagai upaya penyebarluasan info layanan zakat sekaligus memperbanyak muzaki yang menggunakan layanan zakat digital.

Keterbatasan pada penelitian ini dapat dijadikan referensi bagi peneliti selanjutnya untuk melengkapinya. Peneliti selanjutnya dapat melakukan pengembangan model SEM dengan cara menghubungkan beberapa konstruk laten yang tidak terhubung dalam penelitian ini dengan menggunakan teori-teori pendukung model tersebut. kemudian, peneliti selanjutnya sebaiknya menambahkan faktor lain yang dapat menggambarkan minat sesorang untuk menggunakan produk atau layanan seperti kepercayaan (trust), privasi (privacy) maupun menambahkan variabel eksternal berdasarkan teori TAM 2.

\section{DAFTAR PUSTAKA}

Adhiatma, A. \& Fachrunnisa, O. (2021). The relationship among zakat maal, altruism and work life quality. International Journal of Zakat, 6(1), 71-94.

Amalia, S. N. A. (2018). Faktor-faktor yang mempengaruhi minat individu terhadap financial technology (fintech) syariah (Paytren) sebagai salah satu alat transaksi pembayaran (pendekatan Technology Acceptance Model (TAM) dan Theory of Planned Behavior (TPB)). Iqtishaduna, 9(1), 64-79.

[BAZNAS] Badan Amil Zakat Nasional. (2020). Statistik Zakat Nasional 2019 [Internet]. [diakses 2021 Mar 10]. Tersedia pada: https://pid.baznas.go.id/wp-content/uploads/2020/09/STATISTI K-ZAKAT-NASIONAL-2019.pdf.

[BPS] Badan Pusat Statistik. (2016). Perempuan dan Laki-laki di Indonesia 2016 [Internet]. [diakses 2020 Jan 12]. Tersedia pada: https://www.bps.go.id/publication/2017/12/25/e9f97e642645640c 15caf139/perempuan-dan-laki-laki-di-indonesia-2016.html.

Celik, H. E. \& Yilmaz, V. (2011). Extending the technology acceptance model for adoption of eshopping by consumers in Turkey. Journal of Electronic Commerce Research, 12(2), 152.

Davis, F. D., Bagozzi, R. P. \& Warshaw, P. R. (1989). User acceptance of computer technology: A comparison of two theoretical models. Management Science, 35(8), 982-1003.

Duy, N. K. (2012). Factors affecting behavioral intentions toward mobile banking usage: A study of banking customers in Ho Chi Minh City.

Firmansyah, F. (2013). Zakat sebagai instrumen pengentasan kemiskinan dan kesenjangan pendapatan. Jurnal Ekonomi dan Pembangunan, 21(2), 179-190.

Ghozali, I. \& Latan, H. (2015). Partial Least Squares: Konsep, Teknik dan Aplikasi Menggunakan Program SmartPLS 3.0 untuk Penelitian Empiris. Semarang (ID), Badan Penerbit UNDIP.

Haryono, S. (2017). Metode SEM untuk Penelitian Manajemen dengan Amos Lisrel PLS. Jakarta (ID), Luxima Metro Media.

Hudaefi, F. A. (2020). How does Islamic fintech promote the SDGs? Qualitative evidence from Indonesia. Qualitative Research in Financial Markets, 353-366.

Hudaefi, F. A., Beik, I. S., Zaenal, M. H., Choirin, M., Farchatunnisa, H., \& Junari, U. L. (2020). 
How does zakat institution respond to fintech? Evidence from BAZNAS Indonesia. International Journal of Zakat and Islamic Philanthropy, 1-8.

Indrayana, B., Seminar, K. B., \& Sartono, B. (2016). Faktor penentu minat penggunaan instagram untuk pembelian online menggunakan Technology Acceptance Model (TAM) dan Theory of Planned Behavior (TPB). Jurnal Aplikasi Bisnis Dan Manajemen, 2(2), 138-147.

Irhamsyah, A. (2019). Analisis Faktor-Faktor Preferensi yang Mempengaruhi Keputusan Metode Pembayaran Zakat Bagi Muzakki Di Era Digital (Studi pada Dosen dan Tenaga Kependidikan Fakultas Ekonomi Dan Bisnis Universitas Brawijaya). (Disertasi, Universitas Brawijaya, Malang, Indonesia).

Jogiyanto, H.M. (2007). Sistem Informasi Keperilakuan. Yogyakarta (ID), Andi.

Khalil, N. M., Amin, H. \& Azman, N. S. (2020). Compliance intention to pay zakat on salary: A case from East Malaysia. International Journal of Zakat, 37-50.

Kholid, M. N. (2018). Keberterimaan muzaki terhadap zakat crowdfunding di Indonesia: Preliminary research. CIMAE: Conference on Islamic Management Accounting and Economics, 1(1), 52 58.

[Kitabisa] Kitabisa.com. (2016). Indonesia Online Giving Report: Kitabisa.com 2016 [Internet]. [diakses 2020 Feb 28]. Tersedia pada: https://blog.kitabisa.com/indonesia-online-givingreport-kitabisa-com-2016/.

[Kitabisa] Kitabisa.com. (2018). Kitabisa.com Online Giving Report 2018: Indonesia Negara Paling Dermawan di Dunia [Internet]. [diakses 2020 Feb 28]. Tersedia pada: https://blog.kitabisa.com/kitabisa-online-giving-report-2018-indonesia/.

Mahendra, T. (2014). Minat Individu terhadap Penggunaan Mobile Banking: Pendekatan Modified Technologi Acceptance Model (TAM) dan Theory of Planned Behavior (TPB). (Disertasi, Universitas Brawijaya, Malang, Indonesia).

Thaker, M. A. M. T., Thaker, H. M. T. \& Pitchay, A. A. (2018). Modeling crowdfunders' behavioral intention to adopt the crowdfunding-waqf model (CWM) in Malaysia: The theory of the technology acceptance model. International Journal of Islamic and Middle Eastern Finance and Management, 11(2), 231-249.

Muneeza, A. \& Nadwi, S. (2019). The potential of application of technology-based innovations for zakat administration in India. International Journal of Zakat, 4(2), 87-100.

Salleh, M. C. M. \& Chowdhury, M. A. (2020). Technological transformation in Malaysian zakat institutions. International Journal of Zakat, 5(3), 44-56.

Sarwat, A. (2019). Ensiklopedia Fikih Indonesia 4: Zakat. Jakarta (ID): PT Gramedia Pustaka Utama.

Soekapdjo, S., Tribudhi, D. A. \& Nugroho, L. (2019). Fintech di era digital untuk meningkatkan kinerja ZIS di Indonesia. Jurnal Ilmiah Ekonomi Islam, 5(3), 137-144.

Suhendra. (2017). Benarkah RI negara dengan penduduk Muslim terbesar dunia? [Internet]. [diakses 2020 Jan 12]. Tersedia pada: https://tirto.id/benarkah-ri-negara-dengan-penduduk-muslimterbesar-dunia-cuGD.

Sulaeman, S. \& Ninglasari, S. Y. (2020). Analyzing the behavioral intention factors in using zakatbased crowdfunding platform in Indonesia. International Journal of Zakat, 5(3), 1-19.

Suyanto, S., \& Kurniawan, T. A. (2019). Faktor yang mempengaruhi tingkat kepercayaan penggunaan fintech pada UMKM dengan menggunakan Technology Acceptance Model (TAM). Akmenika: Jurnal Akuntansi dan Manajemen, 16(1), 175-186.

Wildan, M. (2019). Pengaruh Persepsi Kemudahan Penggunaan, Efektivitas dan Risiko terhadap Minat Bertransaksi Menggunakan Financial Technology (Fintech). (Disertasi, Universitas Islam Negeri Walisongo, Semarang, Indonesia). 